\title{
The Newly Discovered Treatise on Patriarch Nikon in the Cultural and Historical Context of Its Epoch
}

\author{
Svetlana K. Sevastyanova
}

I. I. Polzunov Altai State Technical University, Barnaul, Institute of Philology of the Siberian Branch of Russian Academy of Sciences, Novosibirsk, Russia sevask@mail.ru

\begin{abstract}
The newly discovered anonymous treatise on the deposed Patriarch Nikon (1652-1656, $\dagger 1681$ ) belongs to the short-lived Russian seventeenth-century theological and political tradition inaugurated by Nikon himself, where the place of the Patriarch was considered as incomparably superior to that of any secular ruler including the tsar of the Muscovite Rus'. The written monuments of this tradition are rare and mostly include (rather little-known, too) works by Nikon. In the present treatise, the tsar is accused that he is the main culprit of all contemporary evils fallen on the Russian Church, whereas the so-called "schismatics" (the Old Believers - those who stood against Nikon's Church reforms) are only a secondary target of anonymous author's criticisms. The copying of such a dissident work would have become dangerous in the late 17 th century under the first Russian Emperor Peter the Great. Therefore, its copy, the uniquely preserved one, was deliberately "concealed" within a manuscript collection of Nikon's works.
\end{abstract}

\section{Keywords}

Church - political theories - Muscovite Rus' - Patriarch Nikon of Moscow - Russian Old Believers

\section{The Newly Discovered Treatise}

In the process of comparison of the texts of fourteen copies of the Objection (Возраженіе) by Patriarch Nikon with Boyar S. L. Streshnev's questions and answers to them by Paisius Ligarides, Metropolitan of Gaza, I have found that 
the final (the 27th) answer in one of the texts contained an ending unknown in other copies. The text of the Objection and some following articles in the manuscript of the Russian State Library, coll. 178 (the Museum Coll.) Nr 9427,

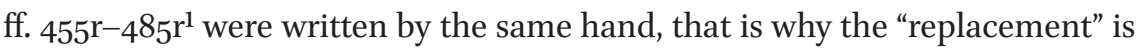
difficult to be detected.

An appreciable border between the traditional variant of the text of the Chapter 27 from the new ending is a slightly visible note at the line in the form of a small point crossed with a short horizontal stroke; such a sign is not typical of the manuscript which includes not only the Objection but several compositions by Patriarch Nikon and his contemporaries: all of them have their own titles or - in the absence of them - are started on new pages. Another indication at the new text is located on the left margin (near the binding): there are two words written vertically with Cyrillic letters телосъ к:н:u: (that is, $\tau \dot{\lambda} \lambda$ оs $\kappa<0>H<e>\mathrm{u}<\boldsymbol{\gamma}>$ "end"); the word телосъ ( $\tau \dot{\varepsilon} \lambda \circ \varsigma$ ) is placed aside the sixth and the seventh lines from above - a little over the beginning of the new text (the 14th line from 24 lines on the page); so, not reading the text on the page, we cannot understand which "end" was marked with that sign. The third indication is in the header on the p. $454 \mathrm{v}$ - the one before the page with the new text; the header contains a note in square brackets: 27-е возражение (the 27th objection); there is a note на 27-ü вопрос и ответ (at the 27 th question - an answer) on f. $455 \mathrm{r}$ where there is a border between the old and the new texts; there are no more headers from $\mathrm{f} .455 \mathrm{v}$ onwards.

Another feature of that variant of the text consists of numerous notes in square brackets inside the lines and among them. It makes the newly detected text look like the testament - the rules by Patriarch Nikon, a copy of which in the same manuscript appears with inserts in line spacing, including those

1 For a detailed description of the manuscript see: С. К. Севастьянова, Эпистолярное наследие патриарха Никона. Переписка с современниками: Исследование и тексты [S. K. Sevastyanova, Epistolary Heritage of Patriarch Nikon. Correspondence with Contemporaries: Research and Texts], Moscow, 2007, p. 328. A watermark "a bellcap with seven bells" on sheets with the newly found composition was identified by me; s. Т. В. Дианова, Л. М. Костюхина, Водяные знаки рукописей России хVII в. [T. V. Dianova, L. M. Kostiukhina, Watermarks of Manuscripts of Russia of the Seventeenth Century], Moscow, 1980, Nr 474 (1678, 1685), Nr 475 (1685). Further the text from this manuscript will be cited with references on the certain sheets - in round brackets. For a preliminary publication of the text see: С. К. Севастьянова, “Новонайденное сочинение о патриархе Никоне” [S. K. Sevastyanova, “The Newly Found Composition about Patriarch Nikon"] in: Культура, история и литература Русского мира: Общенаииональный и региональный аспекты, Barnaul, 2014, pp. 335-380. 
naming Nikon as the author of the composition. ${ }^{2}$ In both cases, the notes were made with one and the same hand as the main texts - it testifies to the work of an editor. But inserts and additions to the newly detected variant of the Objections are more diverse in their content. A part of those notes stressed one of the most characteristic ideas of Nikon based on the words of St John Chrysostom on the priesthood which is "higher than tsardom" ( $\alpha \nu \omega \tau \varepsilon \dot{\varepsilon} \omega \omega \alpha \sigma i \lambda \varepsilon i \alpha \varsigma$, cf. $i \varepsilon \rho \omega \sigma \dot{v} \eta \eta \beta \alpha \sigma i \lambda \varepsilon i \alpha \varsigma \mu \varepsilon i \zeta \omega \nu)^{3}$ (hereafter the inserts in the line spacing and other notes are shown with bold): the Church "from bishop, not from tsar, is sanctified with prayers and anointed with holy unction" (f. 459r); "the Christian Church is a vineyard for apostles, patriarchs and other bishops who create it, not for earthen tsars, given by Lord". Other notes were designed to decorate the style, to make it more florid: междоусобства всепрезлая (f. 466v), предподаждь всем (f. 468r); всепреприятно (f. 469v), превозлюбленнии, всепрекрасное (f. 472r); о преди предреченных, предстрашных и предужасных (f. 474v), богопреддостойныя (f. 477v), всепредзлобнаго (f. 482v). Асcording the content of the following notes, they were made after the comparison of the text with the original; someone restored missed words and phrases: "in the memory of that evil they came to understanding" (f. $458 \mathrm{r}$ ), "they will leave the action" (f. 462v), "a man [...] not accepted and not covered with the divine grace of God" (f. 464v); some words were changed to other ones: the council "perfect" (совершеннаго) instead of "sanctified" (освященнаго) (f. 48ov), монах instead of инок (both mean "monk") (f. 484v), созериаю instead of созираю (both mean "observe") (f. $485 \mathrm{r}$ ), and others. It is noteworthy that the scribe read the text rather thoroughly; he wanted to pay attention to certain fragments and topics of the composition with notes on the margins of the manuscript.

Reading the text allows to detect its stylistic peculiarities. The most important of them was a change of the narrator from an anonymous author to Patriarch Nikon and back: "By the God's Grace, Patriarch Nikon said it not because of the weak mind" (f. 455r); "And if the tsar and ruler want to do it with Nikon the Patriarch [...] I am ready to inherit everything. And I do not refuse it, if God orders me. As it was under my election at the patriarchy, I said such words to the tsar as a testimony" (f. 455v); "And I, Nikon, Patriarch by God's Grace, tell you so" (f. 464r); "Peacefully enjoy yourself, Nikon, thanks to your victories, and gird yourself about with more patience" (f. 484 r). In this aspect, the new

2 С. К. Севастьянова, “Завещание-устав патриарха Никона” [S. K. Sevastyanova, "The Last Will and the Rule by Patriarch Nikon"], Вестник Томского гос. пед. унив-та (2004), $\mathrm{Nr} 2$ (39), pp. 138-144.

3 PG 48, col. 640-641; PG 56, col. 127. 
variant of the Chapter 27 resembles the final part of the Chapter 26 , where a narration from the name of Patriarch Nikon was changed to that of another person. It is noteworthy that an anonymous narrator appeared in both chapters in the cases when some details of Nikon's biography were performed - by the way, such elements were almost absent in spiritual-didactic compositions and epistles by the patriarch himself.

As was already said, the new addition to Chapter 27 was connected with the earlier text in the middle of the line, just after the commentary on the 84th Rule of the Holy Apostles. There is an obvious lexical and semantic similarity between that rule and the new fragment (it is shown in the following table with the underlined text).

Objection Chapter 27, a copy of the State Historical Museum, Coll. of the Resurrection Monastery, Nr 132, ff. $960 \mathrm{r}-961 \mathrm{r}$

And he should be presented to the tsar. And if he said it because of the weak mind, let them not take care about him, and if because of some madness, let him be forgiven [...] See you, wri//ter of lie, how it was said by God-bearing holy fathers?
Objection Chapter 27, a copy of the Russian State Library, the Museum Coll., Nr 9427,

f. $455^{\mathrm{r}}$

And he should be presented to the tsar. And if he said it because of the weak mind, let them not take care about him, and if because of some madness, let him be forgiven [...] By the God' Grace, Patriarch Nikon said it not because of the weak mind and not because of some madness, but for the offence of the House of God, I say, the Holy Church, and he stood because of the false trial.

The new content of the Chapter 27 demonstrates at once that its further development will be filled with citations from Patriarch Nikon for the sake of protection of the Church and priesthood. The narration is actually built as a didactic message to the contemporaries of Nikon - exactly, to two kinds of people: to numerous faithful people of the Russian Church, including monastic brethren ("brethren and beloved children," "beloved and holy slaves of God and sons of Our Lord," "brothers and children greatly beloved and greatly desired," "my brethren"), and personally to the tsar. Calling on the congregation, the preacher asks them to keep Orthodoxy in its purity; teaching about the dominant role of the Church in spiritual and common life of people, he calls on everybody to keep and to increase the role of the Church with their labours and spiritual deeds. The tsar was called a person responsible for miserable events in the Church; the author wrote a direct accusative call to the tsar on behalf of Nikon: 
You, the tsar, came into the most holy church yard not through the door, but you crawled over the barrier and attacked him with a trial, as if you are a thief or a robber. And I stood against you face to face in those things because of the offense of the Church and for ecclesiastical things, i.e. for the property of widows and orphans, and because of your unjust trials, as has been written in all the books in a detailed way, really true (f. 482v).

The final words of the fragment prove an obvious connection of the new chapter with a complete polemical book by Patriarch Nikon, as if they summarize the polemic between the disgraced patriarch and his opponents, which was performed in the Objection. Let me remind, that Nikon answered 30 questionsanswers by Streshnev-Ligarides, but all known copies of his composition stop suddenly at the Chapter 27, which is not finished either. According to a testimony of Ivan Shusherin, a biographer of Nikon, the patriarch brought his $\mathrm{Ob}$ jection to the Moscow Council of $1666,{ }^{4}$ but the hagiographer did not mention, whether the composition had already been finished or not. Perhaps, the book was undone, and the new answer was composed in such way to design a logical final for it, to stress the key topics actual for the patriarch, his contemporaries, and the contemporaries of the author. In the last decades of the seventeenth century, when the Church - as the author says - was passing through "dissections and tearing," "persecutions and discords," and "predominance," there was a necessity to consider the personality of Nikon, his ideas, and some of his deeds in the context of tendencies characteristic for the Russian history of the second half of the seventeenth century: strengthening the tsar's authority and its sacralisation, Church dissent in Russia and the coming secularization, which led to a weakening of the role of the Church in the spiritual and common life of people. In the 1680 s and the 1690 s, when the manuscript was produced, the activity of the zealots of piety was especially great; they were writers of the patriarch's circle, which supported Nikon's ideas on priesthood and tsardom based on canonical principles; in their works they developed themes of the dominant role of the Church in the spiritual life of society and state, its inner unity and opposition to Western influence - all those ideas were brightly formulated by Nikon. ${ }^{5}$ But at the very end of the seventeenth century, when

4 Известие о рождении и о воспитании и о житии святейшего Никона патриарха Московского и всея России, написанное клириком его Иоанном Шушериным [A Note on the Deliverance and Bringing Up and on the Life of His Holiness Nikon, Patriarch of Moscow and All Russia, Written by His Cleric Ioann Shusherin], Moscow, 1871, p. 54.

5 Т. В. Панич, Писатели патриаршего круга в богословской полемике 80-x-9o-х г2. ХVII в. [Т. V. Panich, Writers of the Patriarch Circle in Theological Polemic of the 1680-s-1690-s. Author's 
the authority received "a special sacred status, a special charisma," ${ }^{\prime 6}$ and the tsar himself, together with his closest milieu, created an image of Nikon as a "Popist," power-hungry and money-grabber. ${ }^{7}$ In such case an open propaganda of his ideas was hardly possible. That is why, the new text could be included at the end of the book and not separated as a chapter; visually it was melded with the final answer of the patriarch as if hidden inside it. Doing so, the author made his own text available for reading and consideration of those who retained interest in the destiny of the disgraced patriarch even in the late seventeenth century, and who kept the future of the Russian Orthodox Church close to their hearts.

The above mentioned feature of the visual presentation of the new chapter (absence of headings, the word "end" in the margin, a note signalling the beginning of the new text) allows us to come to the conclusion that the compiler considered his own work not only in the general context of the polemical book by Patriarch Nikon as well but also as a self-standing composition; stressing the visual independence of the chapter from the Objection, the author kept a certain logic of narration and paid special attention to the content of ideas and acts of Nikon which could not be easily and unequivocally interpreted even at the patriarch's life-time. I would accent the main topics of the newly found composition, closely connected to the personality of Nikon; then, I will provide a short interpretation of them.

Abstract of the Doctoral Thesis in Philology], Novosibirsk, 2007; Т. В. Панич, Книга Щит веры в историко-литературном контексте конца XVII века [T. V. Panich, The Book of The Shield of Faith in Historical and Literary Context of the late Seventeenth Century] Novosibirsk, 2004, pp. 35, 39-41.

6 Б. А. Успенский, Царь и патриарх: харизма власти в России (Византийская модель и ее русское переосмысление) [В. A. Ouspensky, Tsar and Patriarch: the Charisme of Power in Russia (A Byzantine Model and Its Russian Re-Interpretation], Moscow, 1998, pp. 14-30; Б. A. Успенский, Царь и император. Помазание на царство и семантика монарших титулов [B. A. Ouspensky, Tsar and Emperor. The Chrysm and the Semantic of the Royal Titles], Moscow, 2000, p. 30.

7 “Рассказ Петра Великого о патриархе Никоне," с примечаниями протоиерея Петра Алексеева ["A Narration of Peter the Great about Patriarch Nikon" with Commentaries by archpriest Petr Alexeev], in: Русский архив (1863), book 1, pp. 697-707; Н. С-н, "Рассказ Петра Великого о Никоне патриархе" [N. S-n, "A Narration of Peter the Great about Patriarch Nikon”], in: Русский вестник, 49 (1864), pp. 321-333. 


\section{The Greatness of the Church and Its Distinctive Features}

The anonymous author presents four distinctive features of the Church on behalf of Patriarch Nikon: its unity, sanctity, conciliarity, and apostolic nature. Considering the topic, the author was following the Byzantine Fathers. He is heavily dependent on the important seventeenth-century publications of the Patriarchate of Moscow, The Book of Faith and The Tablet (Skrizhal'). He chose canonical rules and dogmatic arguments from there to prove his main statements. Our unknown writer used Chapter 98 of that book On the Confession of Faith (ff. 318r-361r); he took a long fragment from The Twelve Parts of the Faith (ff. 321r-355r) with comments on the distinctive features of the Church from that chapter. Let us take one example:

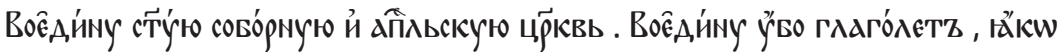

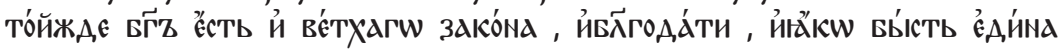

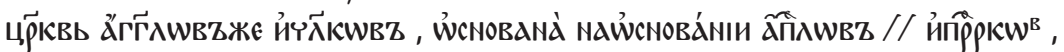

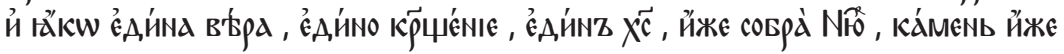

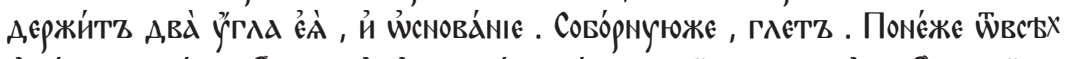

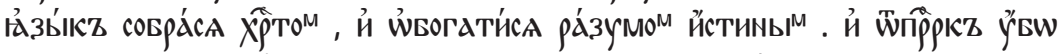

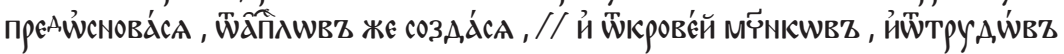

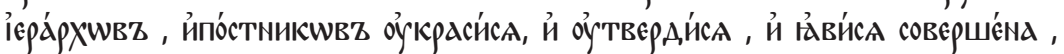

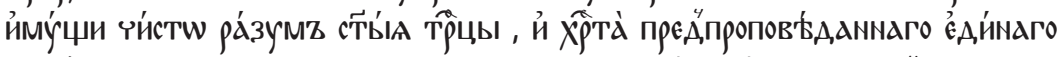

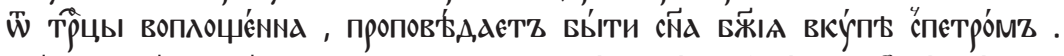

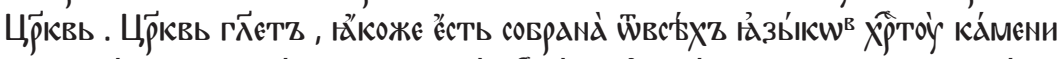

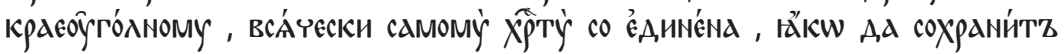
невредй́му в'ьру ёгї. 8

So, we believe and confess that the Church is One, Holy, Universal (Catholic) and Apostolic, and that the God is the one of the Old Law and Grace. And also that the Church is one for angels and people. And also that the Faith is one and the Baptism is one, and Christ is one, Who founded it. We call the Church Universal because all people united thanks to Christ, that it is enriched with the wisdom of the Truth, founded by Prophets and created by Apostles, decorated and strengthened with blood of Martyrs and works of its Hierarchs and Fasters, and it is perfect [...] It is known that the Church is founded on the corner stone, Christ, and it can not be separated from Him, it keeps His Faith intact (ff. 468v-46gr).

8 Скрижаль [Tablet], Moscow, 1655-1656, pp. 434, 435, 438. 
Discussing the sources of Orthodox doctrine, the author turned to the first chapter of the printed compilation From Where the Doctrine of the True Faith Has Come; he combined free citation of the source and its loose interpretation to demonstrate the canonical bases of the Catholic Apostolic Church:

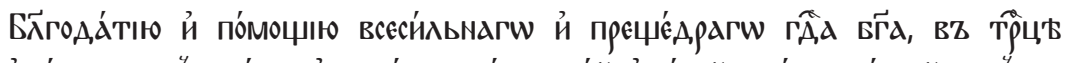

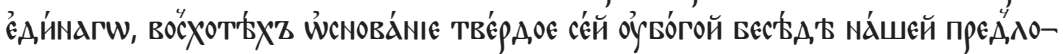

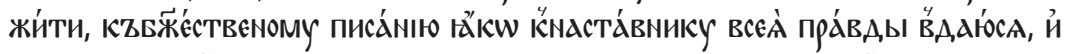

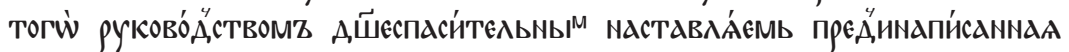

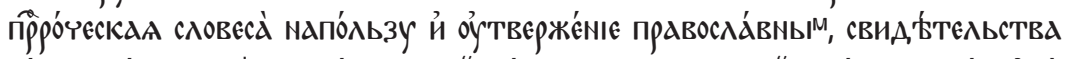

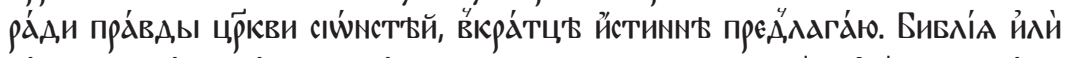

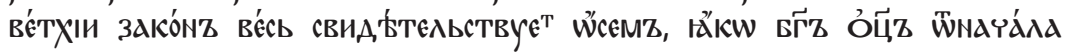

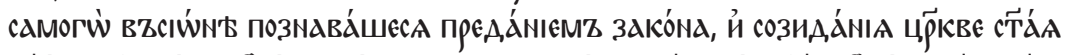

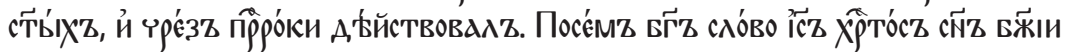

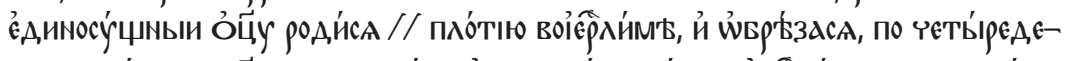

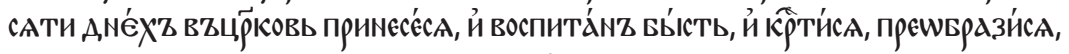

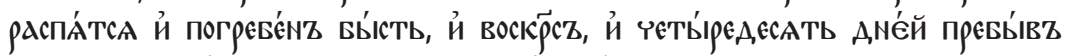

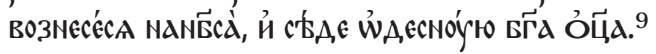

I offer these apostolic words for the sake of the good and consolidation of Orthodox people to testify the truth of the Church of Sion, because on Sion God the Father was known through the Law. Then, God the Word, Jesus Christ, the Son of God, consubstantial to the Father, was born bodily in Jerusalem, there was circumcised and brought into the church and brought up, and He was baptized and resurrected, He ascended to heavens and sat at the right of God the Father (ff. $468 v$ ).

The second part (under the title On the Glory of the Church) of the second chapter On the One Holy Eastern Church and its Glory became one more source of citations. The author took fragments from several compositions by St John Chrysostom and expertly combined them with the topic of numerous names of the Church which stressed its timeless and non-historical, eternal character:

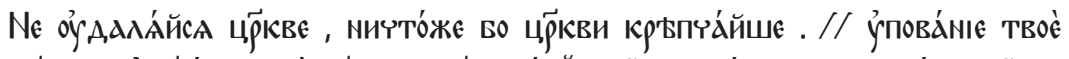

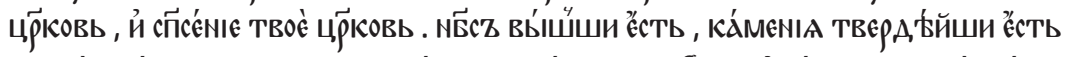

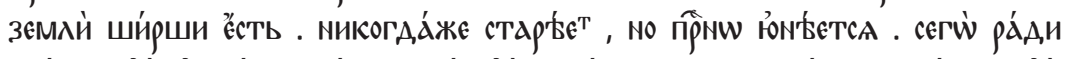

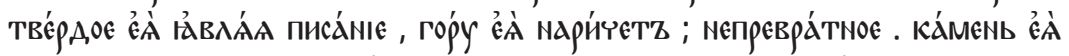

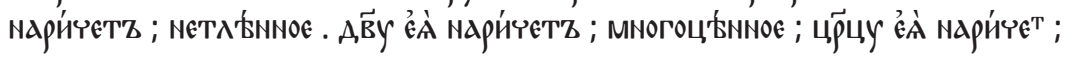

9 Книга о вере [The Book of Faith], Moscow, 1648, pp. 10-11. 


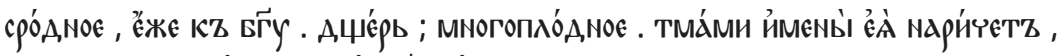

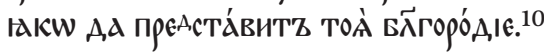

Do not withdraw, man, from the Holy Church. There is nothing in the world stronger than the Church. The Church is your confidence and salvation. It is higher and broader than the heavens, harder than stone and broader than the earth, it never ages but always becomes younger. That is why God, demonstrating to us its strength, calls it Mountain; demonstrating its immutability and stability, calls it Stone; demonstrating its purity, calls it Virgin; and showing its high value, calls it tsarina; because of its proximity to God, calls it Daughter. The many names given to the Church reveal its inner noble entity (ff. 470r-471r).

The author used also the seventh chapter of The Book of Faith, called Testimonies of the Holy Scriptures that Jesus Christ, Our Savior, is the Head, the Shepherd, the Archpriest and the Foundation. He took a fragment on the names of Jesus Christ from it: the Stone, the Foundation, the Root, the Shepherd, the Lamb, the Life, the Light, the Muscle, the Robe, the Trapeza, the House, the Head, the Bridegroom, the Most-Pure, the Lord. All those metaphoric names were mentioned to prove the unity of the Church which existed in love and obedience to God and led people to salvation.

Characteristics of the essence of the Church taken from the publications of the seventeenth century were completed with extracts from liturgical sources and the author's considerations on the topic based on Patristic texts.

The composition openes with the definition of the Church which could be traced back to so called Commented Liturgy, a compilation of the late thirteenth - early fourteenth centuries including no fewer than eleven various commentaries on the liturgy known in pre-Mongolian Russia. ${ }^{11}$ The first part of the compilation was The Ecclesiastical Narration (Skazanie tserkovnoe), an Old Bulgarian translation of The Ecclesiastical History ascribed to Patriarch St Germanus I of Constantinople in the manuscript tradition. That very fragment from the text by St Germanus was used in the first definition of the Church of the composition central for our research:

\footnotetext{
10 Книга о вере, р. 19.

11 Т. И. Афанасьева, Древнеславянские толкования на литургию в рукописной mpaдuиuи XII-XVI вв. [T. I. Afanasieva, Old-Slavic Commentaries on the Liturgy in the Manuscript Tradition of the Twelfth - Sixteenth Centuries], Moscow, 2012, pp. 7-11.
} 
237Г 238a 2386

[1] ЦрькЫ юеть мо

[2] Аитвиче мБсто

[3] сто Храмz мохи

[4] тв' Храмz вйи .

[5] съБориче Аю, ,ЬMZ

[6] Т'ВАО ХТ̈В ИМА єИ

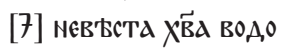

[8] но КОьЧеньА КеГО О

[9] Чицьши са и крZ

[10] ВЬЮ ЕГО ОКРОПАЕНА

[I I] и Nев'БстьскZI oу

[12] творена и Хрнзмо

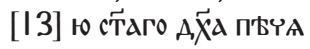

[12] MЬNOF NËO BZ N'S
[1] ТЬА Вющи сА по про

[2] porbckoymoy cגo

[3] веси мVро изАиА

[4] вZШе СА ИМА ТВо

[5] юе и вZ оуХХАнии и мV

[6] ра твогего потекоу

[7] ть имьже זако крI

[8] жьма на гАавоу сZ

[9] ХОААЧИ ПО БРАА,'

[10] Арони .

[1 1] ЦрькZ кеть з'

[13] иже нБ̈сьскZІи Б̈Z

[14] ЖиветЬ И ХОА,ИТЬ

[I5] овразоуночи про

[1 6] Патью и ПогреБе

[17] nье и вZскерьень

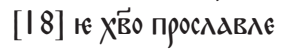

[19] na Паче скиныҢ .

[20] сZв'БА, ВТ'БАЬствА

[2I] MOс'ВовA BZ N'b
[1] иже оц'Фценью

[2] и ст̈аға стTZIX'z

[3] патріархzі оуво

[4] проовражьши

[5] сA АПत̂ZZ OCNOBA

[6] вZШИ СА . И М'NКZІ

[7] Сьврьшьши СА и

[8] СВАТИТТАИ ОУКРА

[9] Шьши сА. ${ }^{3}$

The Church is the earthen heaven, the Temple of God and the Bride of Christ, aspersed with His blood, purified with the water of the Epiphany, giving birth and adopting those who are loyal to it. From the prophetic word, it is adorned as a bride with the grace of the Holy Spirit. The Church is the sea pouring grace, it is similar to chrism coming from the head to the beard of Aaron. The Church is glorified more than the tabernacle of Moses, Patriarchs foretold on it as the Holy of Holies, it was founded by Apostles, perfected by martyrs, adorned by hierarchs; everybody in the Church glorifies God ad He is glorified in heavens (ff. 455 $\mathrm{r}-455 \mathrm{v}$ ).

One more liturgical definition of the Church was taken, obviously, from Skrizhal'. It unites fragments of various chapters of the compilation of liturgical commentaries ascribed in the manuscript tradition to Patriarchs Germanus I of Constantinople and Cyril of Jerusalem:

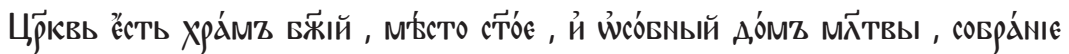

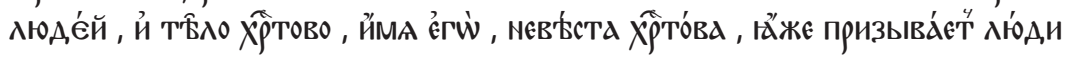




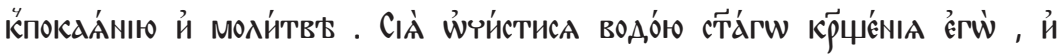

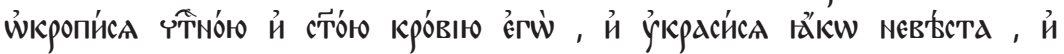

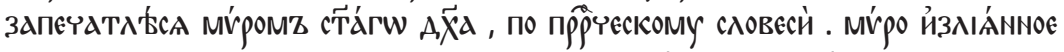

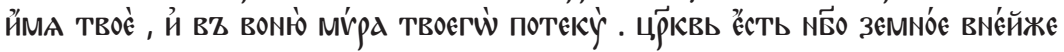
ПреКВЁнЫЙ БГ̈Z всеАÁєТСА. ${ }^{12}$

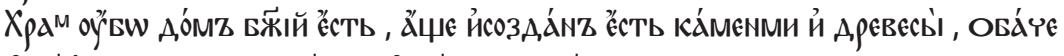

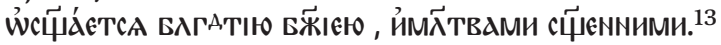

The Church is the House of God, a holy place, a house of prayers and an assembly of people. It is the House of God in spite of the fact it is built of stones and wood. The Church is filled with the grace of God and sacraments. By the archpriest [not by the tsar] it was sanctified with prayers and anointed with oil (f. 459r).

That definition, as well as the first one, was the first expression of the liturgical life of the Church and could be traced back to those liturgical commentaries purposefully mixing concepts of the Church and the Church for the sake of demonstrating the inseparable link between the heavenly and earthen Churches.

The composition contains one more definition of the Church; it is characterized as a spiritual union of people who have common ecclesiastical life, and the rites are performed as a single life cycle of every believer from birth till death:

The Church is the House of God, the refuge and the encouragement for believers. The Holy Church gives birth to all of us through holy baptism and makes us sons and heirs of the Kingdom of God. We fill the holy Divine Church with candles and incense and various wonderful church decorations and we accept sanctification and forgiveness of our sins from it, and all the best things are given to us from the Holy Church. The first gift is our bodily deliverance, the second is baptism with water, the third is the most holy communion, the fourth is after a sin to receive the holy and the second spiritual purification with the fast, prayers and true holy repentance and graceful alms to poor ones, and then the honest marriage and the pure bed, holy and blessed. And after several years, when the time has come to leave this life, we ask God and His Most Pure Mother

12 Скрижаль, р. 11.

13 Ibid., p. 79. 
and all saints to help every true Christian - a son of the Church, a man or a woman, a youth or a girl or a pure child and a saintly baby - to have a quiet, true Christian, Orthodox and holy end from God and all the saints, and to be buried bodily in God's holy church. That is the Orthodox God's Holy Church for us, true believers, it is the second heaven for us and the way to the eternal life which leads us from the death here to the eternal life, to endless rest instead of endless torment (f. 465 r).

The author declares that the Church accompanies each believer through all his or her life; it includes the way of life, the circle of church services and rites, the inner spiritual building and the care of the earthen Church, the spiritual rebirth and death and the way to eternal life. Man receives everything necessary for his salvation in the Church only. There are moral and social laws which are general for all Orthodox people.

Escaping such concepts as Catholic and Universal, the author gives one more definition of the Church to describe on the base of Patristic texts, such features as the absence of limitations with a certain place, time or a certain nation:

The Church exists not in one certain place in the universe but in the space of the whole world. And the Christian law is its foundation. The basis of it is in the spiritual power - not that of an earthen tsar; it exists for preserving the rites of the saint sacraments and keeping the whole people in the Christian law and judging and forgiving (f. 46or).

In his consideration on the essence of the Church the author often uses the words "holy" and "saint" not only as characteristics of distinctive features of the Church but as general epithets of its purity and verity. According to the author, the source and the foundation of the Church lays in Christ and in the Holy Spirit who mystically pours sanctity to everybody coming to the Church and communicating with the sacraments and the liturgy:

The Church is purified with the fire of the Holy Spirit, sanctified with the blood of the Son of God and for ever holy. The Holy Spirit descended on it invisibly as a clear cloud, spreading (piercing) the altar, and it covers, sanctifies and enlightens everybody who serves God. There is the Glory of God and the reasonable victim and singing and praising God in the Church, the Holy Spirit stays invisibly in the most pure and life-giving sacraments of the body and blood of God (f. 459r). 
It is clear that the author's reasoning concerning the Church and its distinctive features were based on Patristic texts on the same topic; they contributed greatly to the completion and broadening of the interpretation of the ninth part of the Creed printed in the Skrizhal', and to the doctrine of the Church and Orthodoxy presented in The Book of Faith.

An important peculiarity of the author's narration is using traditional metaphorical images and symbols of the Church which made the most complicated postulates and concepts more comprehensible and clearer. One of the most best-known metaphors of the Church was a ship:

The Church is likened to ship because it is narrow in the forepart, broad and spacious in the middle and once again narrow and cramped in the stern. As well as a ship, the contemporary Church is oppressed and suffers attacks. Being a communion of believers, the Church is narrow at the beginning of its shape because of the few people who are in it; in the middle the Church-ship is spacious because it gathers numerous peoples dispersed in the universe and brings further the doctrine of saint Apostles; in the end of its shape the Church is narrow and cramped again - it is to be suffering and oppressed under the persecutions from the Antichrist (f. 459v).

The architectural similarity of church and ship was a source of metaphor for the author: he compared three parts of the typical building with the bays of a sea vessel. The symbolism of the ship could be traced back to an early Christian topos ${ }^{14}$ stressing such an important aspect of the sanctity of the Church as its readiness to take aboard not only righteous people but also sinful ones ready for repentance; so, every believer stays in the Church to the extent he or she attains sanctification:

\footnotetext{
А. С. Уваров, Христианская символика, часть 1 [A. S. Uvarov, Christian Symbolism, part 1], Moscow, 1908, pp. 157-163; А. П. Каждан, “Корабль в бурном море. К вопросу о соотношении образной системы и исторических взглядов двух византийских писателей" [А. Р. Kazhdan, "Ship in the Stormy Sea. About the Inter-relations of the Imagery System and Historical Views of Two Byzantine Writers"], in: Из истории средних веков и возрождения, Moscow, 1976, pp. 3-16; Т. В. Кущ, “К проблеме морских образов в поздневизантийской эпистолографии” [T. V. Kushch, "At the Problem of Sea Imagery in the Late Byzantine Epistolography"], in: Античная древность и средние века, 32 (2001), pp. 239-244; Т. А. Миллер, “Образы моря в письмах каппадокийцев и Иоанна Златоуста (Опыт сопоставительного анализа)" [Т. A. Miller, "Images of the Sea in Letters of Cappadocian Fathers and St. John Chrysostom (An Attempt of Comparative Analyses)"], in: Античность и современность, Moscow, 1972, pp. 360-369.
} 
Who does not enter the ship of the Church because of his faith is worth of eternal death. There are good and evil people, righteous and sinful ones in the spiritual ship (f. 459v).

But complete sanctity can be achieved in the future life only. The author used the metaphor of the ship to explain how difficult and narrow would be the way to the Kingdom of Heaven.

An eschatological motive of the trial of faith by the Antichrist was used to express the idea that, in spite of all inner conflicts and accusations from the outside, the Church is afloat thanks to the strength of Orthodoxy:

The Church is similar to a ship in the stormy sea, it suffers from cruel persecutions and accusations of its evil enemies, heretics damned by God and vile for him, dissents hated by God, sinful prosecutors, but it can not be sunk (f. 459v).

It is noteworthy that the image of the persecuted Church was actual in Russia among the Graecophile writers of the late seventeenth century; they stood up for the protection of the Church and the strengthening of its role in society; they wrote on its behalf to express their view on new ideas and current events. In that context, the symbol of the Church as a ship in the stormy sea of life won great popularity. Expressing their vision of the continuous way of true piety, Euphemius of Chudovo ${ }^{15}$ and Callistus, Archbihop of Polotsk and Smolensk used the same image. ${ }^{16}$ As for Patriarch Nikon, the symbol had an architectural and landscape embodiment for him. First of all, it was used in the process of construction of a hermitage by the Resurrection Monastery (New Jerusalem) on the bank of the Istra River where Nikon spend time in solitude and prayers during fasts. ${ }^{17}$ In his exile to the Ferapontovo Monastery Nikon returned to the metaphor of the ship when he built a stone levee on a natural sand bar of Boro-

15 Панич, Книга Щит веры, pp. 39-40, 91.

16 The Russian State Library, Museum Collection Nr 9427, f. 494. I should add that the iconographic type of the Ship of Faith became popular in Russian art after the publication of the collection of homilies by Lazar (Baranovich), Bishop of Chernigov and Novgorod, Meч духовный [The Spiritual Sword], Kiev, 1666; there is a large composition on its title page: a ship led by Jesus Christ who is accompanied by Apostles, Martyrs and Confessors whom the Antichrist tries to menace and another vessel with sinners and heretics.

17 М. Ю. Горячева, “Отходная пустынь Патриарха Никона. Материалы исследований” [M. Yu. Goryacheva, “The Seclusion Hermitage of Patriarch Nikon. Research Materials"], in: Никоновские чтения в музее "Новый Иерусалим", Moscow, 2002, pp. 23-36. 
davskoe Lake; there he set up a cross, and the artificial mound-island was shaped as a ship and a church at the same time. ${ }^{18}$

The anonymous author used one more traditional metaphor of the earthen heaven, declaring:

The Church is called the earthen heaven because it is said in Holy Scripture: We are in the Church as if in heavens. Three ranks of angels are singing, praising God as if on earth, in the holy church three ranks of people are glorifying Him: priests and deacons in the altar, believers and strong in faith in the naos and penitents of the lowest rank in the narthex (f. 459r).

An explanation of the inner structure of the Church as the earthen heavens reveals the reality of the higher degree in it. The hierarchy of heavenly great men of prayers is projected at Christians on the earth - those who are united in the Church on the basis of the unity of principles of communications: faith, love, mutual help and saving common service. The idea of correspondence between the heavenly and ecclesiastical hierarchies as it was expressed by Dionysius the Areopagite was known in Russia from the fourteenth century onwards.

The author used one more traditional symbol of the Church known from the early Christian period - grapes:

The Christian Church is the grapes of Apostles, Patriarchs and other Archpriests, its founders, which was given to them by God - not by the lay tsars (f. 46or).

In Christian symbolism grapes were one of the most best Eucharistic signs; ${ }^{19}$ at the same time, the grapevine with leaves embodied the Universal Church and the unity of all believers, i.e. the Church itself as a community - those meanings of the symbolism of grapes were stressed by the anonymous author of the composition in question.

Metaphorical images and symbols of the Church chosen by the author reflect one more distinctive feature of the Church - to be a visual embodiment both of the earthen and the heaven Church. For Patriarch Nikon, who founded the Resurrection Monastery (New Jerusalem) and reconstructed the holy places of Palestine by Moscow, the Resurrection Cathedral reproducing the Holy

\footnotetext{
18 М. А. Тодорова, “Остров Патриарха Никона в Ферапонтово” [M. A. Todorova, "The Island of Patriarch Nikon in Ferapontovo"] in: Ibid., pp. 41-46.

19 Уваров, Христианская символика, pp. 172-178.
} 
Sepulchre in Jerusalem with its tile decoration, visual symbolism and architectural forms "embodied the concept of the innermost beauty of the Heavenly Jerusalem and reflected the impressions of the earthen beauty of the earthen Jerusalem." The symbolism of tiles on the Resurrection Cathedral reveals the excessive and inexpressible beauty of the future life and partly coincides with images and metaphorical comparisons used by the anonymous author. Styled floral ornament, vine leaves and bunches of grapes at the ceramic frieze correspond to the analogy between the Church and the grapes; symbols of earth and heavens, the holy place and Jerusalem (Mother of Zion in the composition) have semantic parallels with images of cherubim which are associated with the Tabernacle and the Temple of Solomon - prototypes of the two churches, both earthen and heavenly ones. ${ }^{20}$ The marine topic was also typical of ceramic decoration of the Resurrection Cathedral and it was implemented in the ornament as a styled wave with shells. And images of the Church - communion of people, the "refuge" and the "consolation" of believers in the newly discovered treatise - correspond with multinational population of the Resurrection monastery. At the time of Patriarch Nikon, there were about 500 brethren and almost the same number of monastery workers of various nations: Russians, Ukrainians, Belorussians, Greeks and Orthodox Poles, Jews and Germans. Under the spiritual leadership of Nikon, they created a unique monastic complex uniting Old Russian, East Christian and West Russian traditions. ${ }^{21}$

The author thoroughly selected metaphors for the Church and translated symbols of the Church implemented by Nikon in architecture and visual art into verbal formulas: thus, he clearly demonstrated the essence of that theological concept of the Patriarch which was realized in the Churches of New Jerusalem by Moscow and some other monasteries founded by Nikon.

Talking about the sanctity of the Church the anonymous author stays in the frames of historical and literary context of the second half - the end of the seventeenth century: he used liturgical commentaries from the Skrizhal', dogmas of the Orthodox faith and the Church from The Book of Faith and especially popular metaphors of the Church as the ship, the earthen heaven and the grapes. An appeal to early Byzantine sources about the spiritual meaning of the Church, its hierarchical structure and the speculative interpretations of the liturgy was not occasional: at first, the author, who lived in a transitional epoch, used texts composed in similar periods and containing relevant ideas;

\footnotetext{
20 Г. М. Зеленская, Святыни Нового Иерусалима [G. M. Zelenskaya, Shrines of New Jerusalem], Moscow, 2002, pp. 78, 66 .

21 Г. М. Зеленская, Новый Иерусалим. Путеводитель [G. M. Zelenskaya, New Jerusalem. Guide], Moscow, 2003, pp. 24-25.
} 
secondly, in those significant and authoritative Orthodox sources the anonymous author interpreted the Russian Orthodox Church as an heir of Universal Orthodoxy, the protector of the Orthodox doctrine in its initial, canonical and most pure form.

\section{Influence of Other Nations and Other Confessions on the Russian Orthodox Culture and Everyday Life}

According to the anonymous author, Patriarch Nikon made a martyr's death in his relations to the tsar's authority, a similar one to that which had glorified Metropolitan Philip of Moscow. After his liturgical definition of the Church "The Church is the earthen heaven, the Temple of God, and the Bride of Christ"

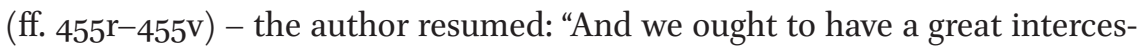
sion for God's Church any way" (f. 455r). The most important duty of its priest was to keep the Church and the Orthodox doctrine itself in their purity and unity; the author regarded a spiritual duty of the high priest as protection of the Church and readiness to suffer for the sake of the true faith.

The similarity between the spiritual deeds of Nikon and Philip was shown in the prophetic words of Nikon addressed to tsar Alexey Mikhailovich pronounced at the coffin with blessed remains of Metropolitan Philip - they were on the readiness of the future patriarch to suffer for the sake of piety. The anonymous author was sure: everything happened between the tsar and the patriarch (after Nikon had taken the see) was a reflection of tragic events at the end of Philip's life; "and see him [Philip. - S. S.] as a mirror, and not do the same with us (f. $455 \mathrm{v}$ ).

The topic of similarity between Nikon and Metropolitan Philip in the martyr's death was developed through a thoroughly gathered assembly of sources. One of them was a marginal note to the introduction to the New Margarite by Prince Andrey Kurbsky. ${ }^{22}$ That short fragment about the metropolitan was composed according to the standards of martyrdom and became a prototype of the later written Life of St. Philip within the The History of the Great Prince of

22 A. M. Kurbskij, Novyj Margarit: Historische-kritische Ausgabe auf der Grundlage der Wolfenbütteler Handschrift, Hrsg. Von I. Auerbach (Bausteine zur Geschichte der Literatur bei den Slawen), Giessen, 1976-1990, Bd. 1-4, Lfg. 1-17, 3 об.; В. В. Калугин, Андрей Курбский и Иван Грозный: (Теоретические взгляды и литературная техника древнерусского писателя) [V. V. Kalugin, Andrey Kurbsky and Ivan the Terrible: (Theoretical Views and Literary Methods of Old Russian Writer)], Moscow, 1998, p. 186; Библиотека литературы древней Руси [Library of the Literature of Old Rus'], Saint Petersburg, 2001, t. XI (XVI век), p. 560 . 
Moscow, in which Kurbsky created impressive and contrasting images of the tyrant tsar Ivan the Terrible and the martyr-saint Philip. ${ }^{23}$ It is noteworthy that the parallel between Philip and Nikon, stressed in that source, does not only concern Nikon's personal approach Nikon to the veneration of Metropolitan Philip, ${ }^{24}$ but on a greater scale it proves that those who supported the patriarch perceived his conflict with the tsar as his martyrdom. Sufferings, hardness in his protection of the true faith in Christ, cross-bearing, gaining of patience, adherence to Christ, and the sanctity of Patriarch Nikon were reflected in epitaphic verses composed in the Resurrection Monastery soon after Nikon was buried there. ${ }^{25}$

Another source was the Prohibition on Skullcaps - an original composition about Metropolitan Philip which was rather popular in the manuscript tradition of the seventeenth century. ${ }^{26}$ If the author of the marginal note drew attention to the sufferings of Philip, who bravely opposed oprichnina: "And talked about the visions of God, having no doubts before the cruel and unhuman tsar and accusing him in his falsehoods and extortions" (f. 455v), the author of the Prohibition on Skullcaps, also stressing the topic of the sufferings of Philip, ${ }^{27}$ at

23 Калугин, Андрей Курбский и Иван Грозньй, pp. 186-189.

24 С. К. Севастьянова, “Патриарх Никон и митрополит Филипп (Колычев): к вопросу о жизненных ориентирах и подобиях" [S. K. Sevastyanova, "Patriarch Nikon and Metropolitan Philipp (Kolychev): On the Problem of Life Trends and Similarities"], in: Соловецкое море: Историко-литературный альманах, Arkhangelsk - Moscow, 2010, $\mathrm{Nr}$ 9, pp. 61-73; eadem, "Патриарх Никон и митрополит Филипп (Колычев): еще раз о жизненных ориентирах и подобиях" ["Patriarch Nikon and Metropolitan Philipp (Kolychev): Once Again on the Problem of Life Trends and Similarities"], in: Соловеикое море: Историко-литературный альманах, Arkhangelsk - Moscow, 2014, Nr 13, pp. 59-70.

25 Г. М. Зеленская, “Почитание памяти Святейшего Патриарха Никона в XVII-XX веках" [G. M. Zelenskaya, "Veneration of the Memory of His Holiness Patriarch Nikon in the Seventeenth - Twentieth Centuries"], in: Никоновские чтения в музее «Новый Иерусалим», Moscow, 2002, pp. 88-98.

26 Introduced by G. G. Latysheva: Г. Г. Латышева, “Публицистический источник по истории опричнины (К вопросу о датировании)" [G. G. Latysheva, "A Publicistic Source on the History of Oprichnina (On the Problem of Date)"], in: Вопросы историографии и источниковедения отечественной истории, Moscow, 1974, pp. 30-62; published by I. A. Lobakova: И. А. Лобакова, Житие митрополита Филиппа: Исследование и тексты [I. A. Lobakova, The Life of Metropolitan Philip: Studies and Texts], Saint Petersburg, 2006, pp. 283-284.

27 Opposite to the Life of Metropolitan Philip and other Russian and foreign sources of the sixteenth century, in this text, they say: the tsar ordered Philip to be put under the iron сар (Латышева, Публицистический источник по истории опричнины, р. 56). 
the same time gave a detailed description of the conflict between the tsar and the metropolitan, who dared to criticize the ruler in a public place: "Righteous tsars ought not to take infidel habits" (f. 457r). Thanks to that text, the topic of the similarity of the patriarch to the metropolitan in the martyr's death acquired a new tone: two fighters for the purity of the Orthodox doctrine were close not only in the type of their behaviour in a conflict with the tsar (open accusation and a lack of fear in the face of death), but the very content of such conflict - disapproval of foreign influences on the Orthodox life style of the Russian people, the strong belief of both high priests that anything foreign would be fatal for religious and everyday life. Putting it in modern terms, Philip and Nikon stood for the self-identity of Russian Orthodox culture, and for keeping its national peculiarities.

For didactic purposes, the anonymous author introduced a topic of the tsar as a supporter of foreign influences and showed how changes in the outlook of Russians produced with simple details of garments taken from foreign ones could hurt the moral state of people; according to the text, the tsar himself, not his oprichniki, wore a skullcap, and that headdress was used by him under inappropriate circumstances. ${ }^{28}$ The problem of "western novelties" coming through the highest lay authorities was quite relevant in the late seventeenth century, when the composition was written. The very image of Metropolitan Philip attracted also Metropolitan Athanasius of Kholmogory to perform his own concepts of those "western influences" on the Holy Church in his polemical anti-Catholic book The Shield of Faith. ${ }^{29}$

It is noteworthy that, in that new text of the late seventeenth century they criticized habits which had become popular in garments and in the general outlook of the highest society since the sixteenth century, ${ }^{30}$ in spite of the fact

28 The Life of Philip says that the metropolitan claimed the tsar Ivan because the latter allowed Oprichniki to stand with skullcaps on their heads in the church; Лобакова, Житие митрополита Филиппа, p. 192 (the Tulupov recension). On the words of B. A. Ouspensky, Metropolitan Philip interpreted skullcaps on Oprichniki as an act of sacrilege: Б. А. Успенский, Избранные труды [В. A. Ouspensky, Selected Works], Moscow, 1996, vol. I, p. 179 .

29 Панич, Книга Щит веры, рp. 82-83.

30 In the seventeenth century, only tsar Mikhail Fedorovich wore the skullcap (it is shown, for instance, in the picture "Sitting of Tsar Mikhail Fedorovich with His Boyars in the State Room" by A. P. Ryabushkin; 1893, Moscow, the State Tretyakov Gallery); according to an inventory, tsar Fedor Alexeevich had two skullcaps; historian I. Zabelin considered they "were made [...] to protect [...] his weak health." - И. Забелин, Домашний быт русских царей в ХVI и ХVII столетиях [I. Zabelin, The Home Customs of Russian Tsars in the Sixteenth and Seventeenth Centuries], Moscow, 2000, vol. 1, part 2, pp. 462-463. 
that the rules of the Hundred-Chapter Council (Stoglav; 1551) radically prohibited Russians from using anything foreign in their everyday life. The author included two fragments from the rules of Stoglav into his narration, Chapter 39 prohibiting the wearing of the skullcap, and Chapter 40 against shaving beards. ${ }^{31}$ The rules of wearing beards had been established long before in all Orthodox legal codices: the Russian Law, Euchologia, and Nomocanons. The absence of a beard or shaving it was considered as a betrayal of Orthodoxy, and priests were refused to bless a shaven man. ${ }^{32}$ From the second half of the seventeenth century onwards, the imitation of a foreign style of appearance had become a constant trend, and usage of foreign objects in everyday life drew in popularity. Western influence penetrated into all spheres of life; as historian V. O. Kliuchevsky wrote, it "turns the outlook and rebuilt the spiritual type of Russians."33

Patriarch Nikon, from whose name the author of the composition delivered a homily for the protection of Russian Orthodox culture from "habits of other confessions" (иноверных обычаев), supported a concept of a solid Orthodox theocratic state living according to the norms of ecclesiastical rites and strict religious rules. He saw the future of Russia not in Greek-Byzantine education, but in keeping and disseminating the basic principles of Orthodox culture. In Nikon's own texts there are no direct testimonies of disapproval of elements of "western life" penetrating into Russian culture and everyday practices, although his contemporaries observed him as a destroyer of "foreign habits," which could "destroy" Orthodox piety, decency, and decorum. Let us remind ourselves of a case of public condemnation and destroying icons of "Fryazi" (Italian) style, expulsion of "Nemtsy" (not exactly Germans, but really various westerners) to the specially built quarter (Nemetskaya Sloboda), or uncompromising hatred between Nikon and Boyar Nikita Ivanovich Romanov, a well-known lover of German music and dress. ${ }^{34}$ One may think that Nikon was dissatisfied with objects brought by tsar Alexey Mikhailovich from the military

$31 \quad$ Е. Б. Емченко, Стоглав: Исследование и текст [Е. В. Emchenko, Stoglav: Study and Text], Moscow, 2000, pp. 301-303.

32 There was a well-known precedent, described by Archpriest Avvakum in his autobiographic Life: in 1648, he refused to bless a son of Voevoda Vassily Petrovich Sheremetev, Mathew, because he had his face shaved, "seeing his "lascivious image" - s. Жuтие протопопа Аввакума, им самим написанное, и другие его сочинения [The Life of Archpriest Avvakum, Written by Himself, and His Other Works], Saint Petersburg, 2010, pp. 19-20.

33 В. О. Ключевский, Русская история: Полный курс лекций [V. O. Klyuchevskiy, Russian History. A Complete Course of Lectures], Moscow - Minsk, 2002, vol. 2, p. 417.

34 А. Олеарий, Описание путешествия в Московию, пер. с нем. А. М. Ловягина [A. Oleariy, A Travel to Moscovia, transl. by A. M. Lovyagin], Smolensk, 2003, p. 168; С. И. Танеев, 
campaign in Poland in 1657 , because it was difficult to associate them with an ideal of the pious life of an Orthodox man - optical tools, tapestries, furniture, musical boxes, lace, cutlery, songbirds, and carriages. ${ }^{35}$ At the same time, there were objects of western origin at the disposal of the patriarch, as well: mirrors, ${ }^{36}$ spectacles, ${ }^{37}$ wide-brimmed hats that were popular among the Western clergy, ${ }^{38}$ dishes; ${ }^{39}$ Nikon used western books on medicine, and on military inventions. ${ }^{40}$

Nikon was sure of the strong faith of tsar Alexey Mikhailovich and, obviously, did not interpret his penchant for western "novelties" in everyday life and ceremonies as a threat to Russian Orthodox culture; some of them simplified life, others corresponded to the rank of the patriarch and the tsar with their luxury and splendour. According to the historian I. Zabelin, in the seventeenth century, an interest in precious and rare objects, including foreign ones, in Russia was still explained with "the amazing character of a piece or with a special complicity of its design and craftsmanship". ${ }^{41}$ In the times before Peter the Great, only a small part of Russian society was ready to accept the forth-

“Публичные концерты и балы в столицах" [S. I. Taneev, "Public Concerts and Balls in the Capitals"], in: Русский архив, Moscow, 1885, Book 3, p. 442.

С. В. Лобачев, Патриарх Никон [S. V. Lobachev, Patriarch Nikon], Saint Petersburg, 2003, p. 201.

36 Н. Гиббенет, Историческое исследование дела патриарха Никона [N. Gibbenet, $A$ Historical Study of the Case of Patriarch Nikon], Saint Petersburg, 1884, part 2, pp. 522-523. Царь Алексей Михайлович и патриарх Никон. "Премудрая двоища" [Tsar Aleхеу Mikhailovich and Patriarch Nikon. "Wise Pair"], Moscow, 2005, p. 80.

38 Nikon was depicted in a wide-brimmed hat with a cross pattern by F. G. Solntsev (Древности Российского государства [...] рисованы Ф. Солниевым [Antiquities of the Russian State [...] drawn by F. Solntsev], Moscow, 1851, dep. 1, Nr 95) and in a famous canvas by V. G. Schwartz "Patriarch Nikon in New Jerusalem". The patriarch was also presented in a wide-brimmed hat in two miniatures of the recension of the Life of Nikon, written by Old Believers - s. Н. Ю. Бубнов, “Старообрядческое «антижитие» патриарха Никона” [N.Ju. Bubnov, “Old Believers' 'Anti-Life' of Nikon”], in: Святые и святыни севернорусских земель, Kargopol, 2002, pp. 221-230.

39 Е. И. Рогожкина, “Личные вещи и вклады Патриарха Никона из фонда драгоценных металлов музея «Новый Иерусалим»" [E. I. Rogozhkina, "Personal Belongings and Donations of Patriarch Nikon from the Collection of Precious Metals of the Museum of 'New Jerusalem'"], in: Никоновские чтения в музее «Новый Иерусалим», Moscow, 2002, pp. $47-56$.

40 Л. Лебедев, Десять московских патриархов [L. Lebedev, Ten Patriarchs of Moscow], Moscow, 1995, p. 55 .

41 И. Забелин, Домашний быт русских иарей в XVI и XVII cm. [I. Zabelin, The Home Customs of Russian Tsars in the Sixteenth and Seventeenth Centuries], Moscow, 1895, p. 244. 
coming reforms. ${ }^{42}$ The "German dress" was taken for fun (poteshnoe), ${ }^{43}$ and in the first years of his reign, tsar Alexey Mikhailovich forbide officially those foreign habits which could produce a harmful influence at the Orthodox mind of Russian people. ${ }^{44}$ Not long before his death, on August 6, 1675 , the tsar, who kept up to the very end traditional Russian and Orthodox positions, issued an order to the highest ranks of the Muscovite state:

foreign German and other habits we did not take, did not cut the hair on our heads, did not wear foreign dresses, jackets (kaftany) and hats, did not copy foreign patterns, and that is why did not permit our people to do it. And if anybody cuts his hair or wears a dress made according to a foreign pattern, or if anybody appears at the public in such dress: let them be in disgrace from the Great Prince, and they are to be sent from higher ranks to lower ones. ${ }^{45}$

As a very Orthodox tsar and in spite of his personal interest in anything foreign in culture, international politics and economics, Alexey Mikhailovich restrained any infiltration of western "novelties" into Russian Orthodox culture, using legal acts and orders against phenomena which could have a negative influence in the religious life of Russian Orthodox society.

Historian Tamara Vasilievna Panich persuasively demonstrated, that in the last quarter of the seventeenth century, an issue of the infiltration of cultural novelties and "foreign habits" (чужестранные обычаи) in the field of everyday life and culture became rather real. The zealots of Orthodoxy connected that problem with a potential influence of the doctrine of the western Catholic Church - such a connection seemed quite logical for them; and that doctrine

42 А. Л. Хорошкевич, “Психологическая готовность россиян к реформам Петра Великого. (К постановке вопроса)" [А. L. Khoroshkevich, "Psychological Readiness of Russians to the Reforms of Peter the Great. (Setting a Problem)"], in: Российское самодержавие и бюрократия: Сб. ст. в честь Натальи Федоровны Демидовой, Моscow, 2000, pp. 158-182.

43 C. М. Шамин, "Мода в России последней четверти XVII столетия" [S. M. Shamin, "Fashion in Russia in the Last Quarter of the Seventeenth Century"], in: Древняя Русь. Вопросы медиевистики, 2005, Nr 1, p. 24.

44 Раскольничьи дела ХVIII столетия, извлеченные из дел Преображенского приказа и Тайной розыскных дел канщелярии Г. Есиповым [Eighteenth-Century Criminal Cases of the Schismatics Found in the Preobrazhensky Prikaz and the Chancellery of Secret Investigations by G. Esipov], Saint Petersburg, 1863, t. 2, p. 67 .

45 Полное собрание законов Российской империи [The Complete Collection of the Law of the Russian Empire] Saint Petersburg, 1830, vol. 1 (from 1649 till 1675), pp. 1007-1008. 
was treated as a crooked, and depraved one, as something far from real piety and faith. ${ }^{46}$ Ecclesiastical writers of the last quarter of the seventeenth century created a general image of a person without a beard, who wore a skullcap, who was under foreign influence both in his appearance and in his behaviour, habits, and his way of life.

Tsar Feodor Alexeevich did not issue any orders prohibiting cutting one's hair or shaving a beard. He even demanded with help of a special rule that men in his service should refuse to wear traditional Russian official dress and should wear a new type of garment which gradually became more and more Europeanised: it was shorter and looked like a Polish dress. Regulations on official appearance included various aspects and opened the way for cosmetics, shaving beards, hairdressing, wearing wigs and adornments, i. e. everything far from Orthodox piety; and such fashion became popular among serving nobility, first of all. ${ }^{47}$ Under the tolerance and silent support of the highest lay authorities toward the process of "westernization" of the Russian way of life, the clerical circles felt it their duty to prevent such tendencies before they passed into the lower classes of Russian society. ${ }^{48}$

Insisting on keeping Orthodox traditions in everyday life and in the appearance of Russians, the anonymous author formulated a typical idea of the zealots of piety. It is not accidental that he chose Patriarch Nikon and Metropolitan Philip whose authority was unflagging till the end of the seventeenth century, as being the brightest and the most instructive examples of the struggle for the purity of Orthodoxy against western and other non-Orthodox and non-Christian confessions and faiths which could penetrate Russian culture.

\section{Social Service of the Church}

From the point of view of the anonymous author, didactic and preaching were the most effective armaments in the battle for Orthodox traditions and culture. He worried that there were few "spiritual men of strong mind and piety"

46 Панич, Книга Щит веры, р. 66; Т. В. Панич, “Духовное завещание патриарха Иоакима” [T. V. Panich, "The Spiritual Last Will of the Patriarch Joachim"], in: Русский мир в мировом контексте: Сб. ст. и матер. конф. с междунар. участием “Человек и мир человека", Rubtsovsk, 2012, p. 222; А. П. Богданов, Русские патриархи (1589-170о), в 2 т. [A. P. Bogdanov, Russian Patriarchs (1589-170o), 2 vols.], Moscow, 1999, vol. 2, p. 328.

47 П. В. Седов, Закат Московского иарства: Царский двор кониа ХVI века [P. V. Sedov, The Dusk of the Moscow Tsardom: the Tsar Court of the End of the Seventeenth Century], Saint Petersburg, 2006, pp. 491-519.

48 Шамин, “Мода в России последней четверти XVII столетия," pp. 37-38. 
(мужей духовных, разумных и благоговейных) among contemporary preachers and ecclesiastical teachers - few of those men who would be able to teach their flock Orthodox law and real piety; that is why he called his readers for praying to the venerated saints of the Orthodox Church:

to entreat Our Lord Jesus Christ, the chief of pastors, to give us His Orthodox pastors, who correctly edited the word of His truth, and let us listen to them, as to the righteous ones, and stay good-minded sheep, quiet and humble before Him constantly, to the Eastern Apostolic Church, and be with it loyally and eternally, adorning ourselves with all good deeds (f. 458r).

The author noted from the name of Patriarch Nikon that preachers of the living word of God were always persecuted and despised; there were always people who did not believe into lessons of such teachers and who demonstrated an open hatred to them, those who abused Orthodoxy and encroached on the power of God with their speeches:

But we hate such good prophets of God, and we close our ears to their voice, like a deaf snake at the sound of trumpets, and we beat envoys not once, and abuse them with slander, we blame their life and work, and we consider them falsely many times, we kill them, and we tear their glory and dignity. In such glory the holy Apostle Paul preferred to meet death but not the inattention of violent listeners, when he said: 'it were better for me to die, than that any man should make my glorying void' (1 Cor. 9:15). When they are beaten with stones, when we oppose God's word of truth in our hard hearts, when we destroy truth with many words from the holy books and the Gospel, they exhort us for the sake of doing good and with Holy Scripture they teach us good customs. As the same chosen vessel of Christ wrote: 'All scripture [is] given by inspiration of God, and [is] profitable for doctrine, for reproof, for correction, for instruction in righteousness: That the man of God may be perfect, thoroughly furnished unto all good works' (2 Tim. 3:16-17) (f. 46or).

Inobedience to the spiritual father and refusal to listen to his preaching, according to the author, lead to doubts in faith, to dissention, and heresies, which destroy the unity of the Church and deform the moral nature of people. That is why teaching spiritual children is the most important duty of any priest as a stalker of souls almost lost in sins. The author declares that the way of life of an Orthodox believer covers several levels of his existence. Some of them are 
located in the sphere of moral and spiritual world - the author calls them "good moods" (добронравие), others are connected with the social milieu and social position of a person, with his interrelations in society; the author calls them "good deeds" (добротворение). In a didactic speech ascribed to Patriarch Nikon, there is a clearly accented topic of spiritual teaching; the author is sure that didactic preaching would form the spiritual and moral character of his contemporaries.

The first lesson which should be given by a teacher is keeping the commandments:

Our Lord Himself wants to ask us about them at the just judgement, horrible and thrilling, and you, too, those seven acts of mercy, as it is written by Mathew the Evangelist in the 25th Chapter: to give meat to the hungry, to give drink to the thirsty, to cloth the naked, to free a man from prison, to visit the sick, to bring a stranger to your home, to bury the dead. And to become righteous into life eternal. (f. 459r)

Following the Christian moral ideal, as if Nikon says, a person did good deads and became virtues, his spiritual and social life would be ordered with the rules of Orthodoxy:

And so, we beseech Our Lord and His Most Blessed Mother Theotokos and Holy Virgin Maria - let Her take any righteous person under Her cover of prayers: a person tender and quiet, humble and good in his habits, without anger and full of patience, pure and faithful, always trusting in God, a voluntary listener of the Word of God, venerating God and having a fear of God, good acting and giving alms according to his ability, adorning holy churches and loving the proper décor of the House of God. (f. $466 \mathrm{v}$ )

Good deeds and their fruits should become a norm, a common rule, a good habit, and a conscious fulfilment of Orthodox regulations.

The second trend of such teaching is the way of life based on the rules and orders of the Church services; a Christian has no right to take part in any actions or entertainments which are far from piety and for that reason are condemned and forbidden by the Church. The author says under the name of Patriarch Nikon:

spiritual advocates must take care of ecclesiastical matters, adornments and all necessary things in the church, as well as about the necessities of 
life and actions of those who serve in the church, and about the poor, and the wanderer," "and Orthodox Christians must not attend prohibited games and performances, and they must not follow barbarous habits, but they should stay far from them.

Orthodox preachers were always against idleness. In the seventeenth century, thanks to the process of intercultural communication and acceptance of some foreign habits by Russians, the topic of piety became quite relevant in the clerical milieu. Calling to the flock, the author once again uses the authority of Patriarch Nikon when he demands people to give up carnal and sinful liaisons which could destroy the moral image of Orthodox Christian:

... and let anger, and rage, daintiness, laziness, and robbery, and all lies, impurity, and charms, and unfaithfulness not find place in us anymore! And that drunkenness and gluttony, and other our evils, with which any man will be impure and void of God's grace. (f. 464v)

Those homilies on piety were based on the centuries-long tradition of preaching which can be traced back to the Church Fathers, but some motives were in tune with ideas of the circle of the so called "zealots of ancient piety" (ревнители древнего благочестия), who argued for the realization of ecclesiastical reforms for the sake of establishing a strict order in Russian spiritual life. We have already mentioned that before coming to the patriarchal see, Nikon shared the ideas of zealots and had been personally acquainted with some of them.

The third didactic topic was connected with the social service of each member of the Orthodox community. The author calls representatives of different social groups to a good and Christian life which would help them to oppose the influence of any other cultures and faiths and to protect the piety of real Orthodox Christians. He built some steps of virtues. The first step includes the godly virtues of Christ: faith, hope, and love (1 Cor 13:13) which were of the greatest importance in the Epistles of the Apostle Paul:

The Son of God, Christ and Our Lord demands various fruits of the ecclesiastical grape from us through such pastors and teachers. He demands the honour of God in the holy service in different ways: He demands the fruit of charity and alms to the poor; obedience - to rulers; patience - for the sick; peace - for offenders; returning - from those who was granted with wonder; love - for those who are full of hatred; patience - for the persecuted; industry - for the lazy; a fruit of care of the flock and prophesying the Word of God from archbishops; a fruit of ecclesiastic service 
- from hierarchs; purity, poverty, and obedience - from monks; a fruit of truth - from judges; almonds to poor - from rich ones; thankfulness and prayer - from poor ones; good rule - from masters; loyalty and diligence - from slaves; and from all of us - faith, love, and hope, and truth. (f. 458v)

Another step of virtues, in the opinion of the author, served as a basis of social prosperity:

The Son of God demands through these holy stalkers of Him - priests, fathers and prophets of His most holy Word - honour of Him equal to that of God: charity, and alms, and obedience, and patience. From offenders and those in vain conflicts He demands peace, from robbers - returning, from those full of hatred - love, from persecuted - patience, from the lazy - active industry, from unrighteous judges He demands a fruit of truth, and from other rich ones - alms to the poor, and from all of us good deeds and prayer, and thankfulness, and very good behaviour. And most of all those, God demands a pure heart in us, where God Himself lives. And we believe in truth and sincerely hope for our salvation. And because of God's grace, let us, brethren, not be vainglorious, envious to each other and offending each other, but be in humility and fear, and we have known and believed the love that God has for us. God is love; and he who dwells in love dwells in God, and God in him (1 John 4:16). (f. 477v)

There is a step of virtues at the basis of the moral doctrine of the Apostles. Their implementation in the spiritual communication of people is the highest ethical aim of the practical life of any person who tries to follow the example of the superior absolute goodness. ${ }^{49}$

The steps of virtues and the homily by Patriarch Nikon on the greatest role of the Church in the social prosperity of people are strikingly similar to the didactic epistles by Patriarch Hadrian to representatives of various estates and groups of Russian society. Twenty-Four Exhortations for Salvation (увещанія, нужная ко спасенію) were delivered by him in the encyclical to the congregation on the occasion of his enthronement in 1690 :

He called for archbishops 'not to accept newly introduced foreign habits, which were penetrating secretly step by step into our holy Eastern Orthodox Church from heretics, Latins, Lutherans, and others, and to stop their

49 Платон (Игумнов), “Добродетель. Священное Писание о Добродетели” [Platon (Igoumnov), "Virtue. The Holy Script on the Virtue"], in: Православная энциклопедия, vol. 15, Moscow, 2007, p. 476 . 
doctrine and not to support it'; he called for monks 'to keep purity, poverty, and humility - because the monastic life is in them'; he called for hierarchs 'to teach regularly how to believe in the Father and Son and Holy Spirit and how to keep the good life'; he asked 'all Orthodox Christians to live righteously, according the dogmas of Eastern Orthodox Church given by the Fathers, in purity and sobriety,' to escape drunkenness and 'drinking tobacco,' not to give 'silver under percents'; he called for princes and Boyars and 'all judges Zemsti - to judge righteously in courts'; he called for warriors - to be obedient to their commanders; he called for parents - to bring their children up 'in punishments, and in bodily purity, and in learning the Holy Scripture'; he called for masters not to offend their subordinates and not to deprive them of necessary things, and he called for slaves of both genders - to respect their masters and mistresses 'working with all thoroughness, and loyalty, and diligence.'50

As well as in the newly found text which we discuss now, a focal point of the epistle by Hadrian was the topic of the universal spiritual role of the Church, extremely important for the late seventeenth century's Russia. The anonymous author developed the idea of the dominancy of the Church in the process of regulating the social behaviour of contemporary people: the general spiritual state of the society depends on the moral self-perfection of each its member, on interrelations of people and social institutions, on authorities and subordinates which are determined by high moral categories. The topic of the Church as a uniting and spiritual leader of the Orthodox state was especially accented also in the homily by Patriarch Nikon.

The fourth topic of his homily was obedience to authorities. On the basis of the quite popular citation from Apostle Paul (Rom 13:1) "Let every soul be subject unto the higher powers; for there is no power but of God, the powers that be are ordained of God" (f. $465 \mathrm{v}$ ), Nikon teaches the flock to be obedient to the authorities; he makes an important remark: fear of authority of any level can be easily overcome by a man who thoroughly fulfils his own duties and acts according Orthodox moral rules:

That is why we ought to obey them according to all examples and be obedient to them in everything, as the servants of God, and respect them with all necessary honour and fear, wherefore you must needs be subject, not only for wrath, but also for conscience sake (Rom. 13:4-5). But I speak not only to the good and humble, but also to the obstinate and 
pretensious, and not for human pleasurer who serves only before their eyes, but you ought to make truth as well when they turned away and to fulfil the ordered. 'Render therefore to all their dues: tribute to whom tribute is due; custom to whom custom; fear to whom fear; honour to whom honour.' (Rom. 13:7). And if any of you, brethren, want not to be afraid of power, they must do what is good before the eyes and when they are turned away, then you have no fear of the power and have praise from Him. (f. 465v)

Christian obedience and humility as an attitude to a person of power elevates a Christian and makes a difference from a liar and hypocrite.

Consequently, Nikon asks those who possess the highest lay power to manifest their Christian charity to subordinates, especially, in legal and disputable cases, taking as a program the biblical doctrine of equality of people in the face of God:

Princes and Voevodas and Judges Zemstii! Judge according to truth: you shall hear the small people and you shall not respect persons in judgement (cf. Deut 1:17), because the judgement of God is according to truth (cf. Rom 2:2); when you judge the small and the great, do it not because of payment and gifts, and do not let strong ones blind your eyes with gains, but give equality to slaves and helpers of youth, revenge to evil ones, be soft with good ones, giving revenge and salvation reasonable in their guilt with your wise fear, saving them from Gehenna's fire; and whatsoever you would that men should not do to you, not do you even so to them (cf. Mt 7:12; Lk 6:31); do not rob in vain and not force them, but be humanly generous and good in heart and righteous, as you would like to be in the God's grace for the sake of your truth. (f. 466r)

It is noteworthy, Patriarch Nikon used the negative formula of the so-called "golden moral rule" delivered in the famous commandment of the Sermon on the Mount: as you want people to treat you, treat them as yourself. In the version by Patriarch Nikon it sounds more like a legal principle than a religious one; it has both ethical and legal parameters as well. The formula was to be interpreted as a civic statement for representatives of the lay judicial authority.

All these topics of the didactic sermon ascribed to Patriarch Nikon in the newly found text were specific to the centuries-long tradition of Patristic homilies; in the last third of the seventeenth century, writers of the patriarch's circle and zealots of piety often discussed those topics. In the course of shaping Russian absolutism, the development of international contacts which led to 
adapting some foreign habits, including those penetrating into the sphere of the religious mind, as well as under the weakening role of the Church in the life of Russian society, the didactic sermon was to present clearly the idea of keeping the traditions of Orthodoxy in the field of spiritual and everyday life. The general essence of that homily by Patriarch Nikon can be compared with encyclicals and didactic sermons by Patriarchs Joachim and Hadrian, Metropolitan Athanasius of Kholmogory, where the actual problem of protecting Orthodoxy and national culture was presented in the context of the traditional topics of Christian didactic literatures connected with moral aspects of life. ${ }^{51}$ Raising the role of the Church, Patriarch Nikon, at the same time, accented the role of the priesthood. He argued that the words delivered by a preacher would be able to heal the soul of one person, as well as society as a whole:

Brethren and my beloved and most desired children! - called Patriarch Nikon. - Let us deprive ourselves of all irregular enmity and discord, and all doubts about holy faith, and hatred among brothers, and internecine combats, and offences, and evil envy, and flattery; and instead of these evil things let us take all holy fighting and most holy love to friends, let us be generous and kind to each other, because God punishes all evil and ugly deeds, or, in other words, executes us with various woes and angriest torments. (f. 466r)

The author was sure, that Orthodox Russians would be able to achieve peace between God and themselves only in the course of building their life according the Christian commandments, and developing pure relations inside their society. He saw it as the only way of keeping true Orthodoxy and the strong Church in Russia.

\section{Patriarch Nikon and the Zealots of Piety}

In the late 1640 s and the early 165 os, future leaders of the Dissent in the Russian Church and Nikon, later Patriarch of Moscow, joined forces for ecclesiastical reforms aimed at the setting the spiritual life of Russia in order. From the nineteenth century onwards, that circle of spiritual and lay persons had been called the zealots of piety, or Theophiles (Bogolubtsy) in Russian historiography. 52

$5^{1}$ Панич, Книга Щит веры, р. 25.

$5^{2}$ Н. Ф. Каптерев, Патриарх Никон и его противники в деле исправления церковных обрядов. Время патриаршества Иосиба [N. F. Kapterev, Patriarch Nikon and His 
There are many studies on zealots from the region of Nizhny Novgorod, ${ }^{53}$ some scholars wrote about their activity, ideas, ${ }^{54}$ and the unity of their artistic system..$^{55}$ In a small number of preserved documents and narrative sources of the early period of the group of zealots there are no testimonies concerning personal contacts of those people with Nikon. Later sources, composed by recognized authorities among Old Believers (former comrades of the patriarch),

Opponents in the Reform of the Ecclesiastical Rites. The Time of Patriarch Joseph], Moscow, 1887, pp. 95-145; idem, Патриарх Никон и иарь Алексей Михайлович [Patriarch Nikon and Tsar Alexey Mikhailovich], Saint Petersburg, 1909, vol. 1, pp. 1-105; С. А. Зеньковский, Русское старообрядчество. Духовные движения ХVII века [S. A. Zen'kovsky, Russian Old Believers. Spiritual Movements of the Seventeenth Century], Moscow, 1995, pp. 102-184; Д. Ф. Полознев, “Русская Православная Церковь в XVII веке” [D. F. Poloznev, "Russian Orthodox Church in the Seventeenth Century"], in: Православная энщиклопедия: Русская православная церковь, Mоscow, 200о, p. 87; Лобачев, Патриарх Никон, pp. 71-75; А. С. Лавров, “Новые данные о «ревнителях благочестия». Документы РгАДА. 16491650 гг." [A. S. Lavrov, "New Data on the 'Zealots of Piety'. Documnts of RGADA 16491650"], in: Исторический Архив, 2008, Nr 1, pp. 195-201.

Н. В. Понырко, “Обновление Макариева Желтоводского монастыря и новые люди XVII в. - ревнители благочестия" [N. V. Ponyrko, "Renovation of the Makariev Zheltovodsky Monastery and New People of the Seventeenth Century - Zealots of Piety"], in: тодрл, vol. 43, Saint Petersburg, 1990, pp. 58-69; Е. Н. Мокшина, "Нижегородский период в жизни патриарха Никона" [E. N. Mokshina, "Nizhegorodsky Period in the Life of Patriarch Nikon"] in: Гуманитарий, 2005, pp. 50-54; eadem, “О нижегородских корнях патриарха Никона" ["On the Nizhegorodsky Roots of Patriarch Nikon"], in: Социально-политические науки, 2012, Nr 2, pp. 17-20; А. В. Морохин, "К истории ранней деятельности ревнителей древнего благочестия" [A. V. Morokhin, "On the History of the Early Activity of Zealots of Old Piety"], in: Российская история, 2010, Nr 6, pp. 115-119; idem, "Нижегородский Вознесенский Печерский монастырь и начальная деятельность 'ревнителей древнего благочестия"' ["The Ascension Pechersky Monastery in Nizhny Novgorod and the Initial Activity of 'Zealots of Old Piety"'], in: Очерки феодальной России, Moscow - Saint Petersburg, 2012, pp. 300-309; idem, "О происхождении патриарха Никона" ["On the Parentage of Patriarch Nikon"], in: Центр и периферия, Moscow, 2012, n. 3, pp. 45-47.

54 В. С. Румянцева, “Кружок Стефана Вонифатьева" [V. S. Rumiantseva, "A Circle of Stefan Vonifat'ev"], in: Общество и государство феодальной России, Moscow, 1975, pp. 178-188; eadem, Народное антищерковное движение в России в ХVII веке [Mass Anti-Ecclesiastic Movement in Russia in the Seventeenth Century], Moscow, 1986, pp. 31-42; еadem, "Стефан Вонифатьев и кружок ревнителей благочестия" ["Stefan Vonifat'ev and the Circle of Zealots of Piety"] in: Исторический лексикон. ХVII век, Moscow, 1998, pp. 473-476.

Е. К. Ромодановская, “Литературное творчество патриарха Никона и старообрядческие писатели” [Е. К. Romodanovskaya, "Literary Works by Patriarch Nikon and the Old Believer Writers"] in: Традиционная духовная и материальная культура русских старообрядческих поселений в странах Европы, Азии и Америки, Novosibirsk, 1990, pp. 58-64. 
contained both negative emotional opinions about the patriarch and his repressive measures, and metaphorical descriptions of Nikon as tormentor, heretic, and apostate, and even a forerunner of the Antichrist. ${ }^{56}$

But the patriarch had never written about his former comrades and their union. The only exception was a question about Bishop Paul of Kolomna and Ivan Neronov, posed by Nikon before Patriarch Paisius of Constantinople in 1654; the answer was published in Skrizhal': Nikon wanted to check that his politics towards enemies of the Church were justified - he meant those who rejected liturgical reform; Nikon needed the support of the patriarch of Constantinople. ${ }^{57}$ In 1662, having left the see, Nikon wrote to tsar Alexey Mikhailovich and mentioned only Ivan Neronov among all the former comrades; Neronov actively persuaded the tsar to call a church council to condemn the acts of Nikon; he also openly blamed the patriarch from the very first days when he took over the see. ${ }^{58}$

In this context, some declarations made under the name of Nikon about his opponents in the newly found text are of special interest. There are only two names of dissentors - those of the greatest significance for the movement of Old Believers: "cursed Avvakum the Archpriest and foul Nikon the Priest" (проклятого Аввакума протопопа и скверного Никиты попа; f. 46or); оnе of the initiators of the dissent, Archpriest Avvakum and an exposer of "newly introduced books by Nikon, the former patriarch", the Priest Nikita Konstantinovich Dobrynin from Suzdal. Both of them were executed in 1682. In spite of the fact, that those religious activists were not acquainted personally, the Old Believers' sources of the late seventeenth and the early eighteenth centuries put them together as the first fighters for the true faith and the martyrs. ${ }^{59} \mathrm{In}$ the well-known martyrology of the Old Believers, The Vinograd of Russia (Виноград Российский), composed by the founder of the Vyg Community and historian of the schism Semen Denisov in the 1730s, there are two chapters about Avvakum and Nikita Dobrynin (4 and 16) with praise of their martyr deeds. ${ }^{60}$

56 Житие протопопа Аввакума, им самим написанное, и другие его сочинения [The Life of Archpriest Avvakum Written by Himself, and His Other Works], Saint Petersburg, 2010, pp. 143-143; Материалы для истории раскола за первое время его существования [Materials fo the History of the Dissent for the First Time of Its Existence], Moscow, 1881, vol. 6, part 3, p. 267.

57 Скрижаль, pp. 411-416.

$5^{8}$ Севастьянова, Эпистолярное наследие патриарха Никона, р. 413.

59 Е. А. Агеева, Е. М. Юхименко, “Добрынин” [Е. A. Ageeva, Е. M.Yukhimenko, “Dobrynin”], in: Православная энииклопедия, vol. 15, Moscow, 2007, pp. 514-516.

6 Виноград Российский, или Описание пострадавших в России за древлецерковное благочестие, написанный Симеоном Дионисиевичем (князь Мышеиким) [The Russian 
The narration about two leaders of Old Believers and "others with them" ( $u$ прочии с ними вси таковии) differs from texts on the other topics in its style and strong accusatory tone. Criticizing the prophets of Old Believers, the anonymous author cites the Bible and compares them with Hymenaeus and Alexander mentioned by the Apostle Paul (1 Tim 1:20), who disseminated false doctrines using their eloquence:

As the holy Apostle Paul sent apostates to torture, he said about them in his Epistle to Timothy remembering: 'some, by rejecting conscience, have made shipwreck of their faith' (1 Tim 1:19). Among them were Hymenaeus and Alexander, given to Satan, they were punished for their offence. (f. 461r)

The polemic character of the narration was strengthened by appellations which were used by the author against his opponents: "schismatics" (раскольники; f. 46ov, 461v), "ароstates" (отступники; f. 46ov, 461r), "possessed" (беснуюшиеся; f. 462r), "madmen" (безумные; f. 461r), "adversaries of the Holy Church" (противницы святьия Церкве; f. 46ov, 461v, 463v, 464r) - they "resisted cruelly the prophesy and interpreted foully Holy Scripture" (проповеданию люте сопротивляются и святая писания зле толкуют; f. 46or). This list of names used for the Old Believers reminds us of publications of the Moscow Printing Yard against Old Believers in the second half of the seventeenth century. They used the same names for those who opposed ecclesiastical reform. ${ }^{61}$ Avvakum and his confederates treated such names as accusations. ${ }^{62}$

To characterize the polemical behaviour of Old Believers the anonymous author used zoomorphic images and analogies, thus describing human features similar to those of some animals. ${ }^{63}$ One of the brightest metaphorical images of the author was the chameleon: "Let them not become similar to

Grapes, or a Description of Martyrs in Russia for Old Church Piety, written by Simeon Dionisievich (Prince Myshetsky)], Moscow, 1906, pp. 1165, 1219.

61 Жезл правления [Staff of Board], Moscow, 1667; Дополнения к Актам историческим [Additions to Acts historical], Saint Petersburg, 1853, vol. 5, Прибавления, pp. 439-510, Nr 102: 1666-1667; Ю. С. Белянкин, Церковь и государство в полемике со старообрядиами во второй половине XVII в. (на примере деятельности Московского Печатного двора). [Yu. S. Beliankin, The Church and the State in the Polemics against the Old Believers in the Second Half of the Seventeenth Century (an Example of the Production by the Moscow Printing Yard)], PhD Thesis (history), Moscow, 2012.

62 Житие протопопа Аввакума, p. 198; Материаль для истории раскола, vol. 6, pp. 201203.

63 М. С. Киселева, Интеллектуальный выбор России второй половины ХVII - начала ХVIII века: от древнерусской книжности кевропейской учености [M. S. Kiseleva, Intel- 
those who become mad at the new moon, and are changed at any time, like chameleon, from colour to colour" (f. 46ov). The description of that animal was taken by the author from the book of Damascene the Studite - Collection of Ancient Philosophers on Certain Features of the Nature of Animals; it was translated by someone from the circle of Euphemius of the Chudov Monastery in the seventeenth century. ${ }^{64}$ That composition was very popular in Russia. It provides an ethical - rather than symbolical and allegorical - interpretation of the features of animals; it was, probably, the reason for the interest of the anonymous author in that text: 65

The chameleon looks like lizard, but in size it is about two cubits, it has a habit of turning into all kinds in an hour, and its fruit is of different appearances, as taraido [taraida, as foreigners say, is instability, or various colours in cereals, or grasses], and that chameleon has no hair, just a body which is never white. His enemy is a big snake living in the same lands, in India, to be precise. It has wisdom from God: when it fights with the snake, it takes a long stick into its mouth, one or two cubits long, and it stands with the stick, as a brave warrior with a sword, and so it fights against snake. And if there are two or three of them, and they take the snake's stick and pull it out of the mouth, then, it draws them to the place, where it has a nest. And there it drops the stick and enters a hole to be free of them. (f. $460 v)^{66}$

lectual Choice of Russia in the Second Half of the Seventeenth - Early Eighteenth Century], Moscow, 2011, p. 273.

64 Д. М. Буланин, “«Физиолог» и «Сокровище» Дамаскина Студита” [D. M. Bulanin, “The Physiologus and the Treasure by Damascene the Studite"], in: Словарь книжников и книжности Древней Руси, vol. 3 (Xvi cent.), part 4, Saint Petersburg, 2004, pp. 154-156.

65 О. В. Белова, “Малоизученный памятник 'Собрание о неких собствах естества животных’ Дамаскина Студита в славянской рукописной традиции. (К проблеме рецепции греческого текста в книжности восточных и южных славян)" [O. V. Belova, "A Poorly Known Work Collection of Ancient Philosophers on Certain Features of the Nature of Animals by Damascene the Studite in Slavic Manuscript Tradition (On the Problem of Reception of Greek Text in the Book Tradition of Eastern and Southern Slavs)"], in: Славянские литературы. Культура и фольклор славянских народов: хІІ Международный съезд славистов (Краков, 1998). Доклады российской делегащии, Moscow, 1998, pp. 82-91; Д. М. Буланин, Античные традиции в древнерусской литературе XI-XVI в8. [D. M. Bulanin, Antique Traditions in Old Russian Literature of the Eleventh-Sixteenth Centuries], München, 1991, pp. 70-74.

66 The text by Damascene the Studite about chameleon is preserved in two manuscripts of the seventeenth century: State Historical Museum, Synodal Coll., Nr 642, f. 146r and Nr 377 , ff. 7or-7ov. 
In Old Russian bestiaries ( quite popular in the manuscript tradition) ${ }^{67}$ the chameleon was not often presented, but in the second half of the seventeenth century, the similarity of the features of that animal with some traits of human behaviour was in demand in Baroque culture: Simeon Polotsky, for instance, used the allegory not once but many times. ${ }^{68}$

A possible reason for choosing the chameleon as a source of the characteristics of 'schismatics' was its inconsistency as well as in biographical facts of some of the Old Believers. It is known that at the church council of 1666-1667 many Old Believers repented; their messages and scrolls with repentance of their the apostasy were read at the meetings of the council; in the nineteenth century, a significant part of those documents was published. But not all of the accused were sincere in their repentance; Priest Nikita Dobrynin, for instance, did not hide that his repentance "was given falsely, to escape execution" (было принесено имъ притворно, ради избежанія казни). Gregory Neronov repented, but later "returned to his previous false beliefs" (на прежнія своя прелести возвратися), but then he repented again. The former deacon of the Annunciation Cathedral in Moscow Feodor Ivanov, a spiritual son of Archpriest Avvakum, repented not at once (as well as Priest Nikita) but only in exile in St. Nicholas Ugresha Monastery. There were only few hard and consistent confessors of the "true faith." Priest Lazar from Romanov was one of such persons, as well as Avvakum; "he not only refused to repent and did not ask to be forgiven, instead of it, he accused the council itself and called its members non-Orthodox" (не токмовъ покаяніе пріиде, или прощенія требова, но весь священный Собор укори и неправославными нарече). Monk Epiphanius from Solovki also did not repent at the council, as well as Feodor Trofimov, a former junior

67 Средневековый бестиарий, вступ. ст. и комм. К. Муратовой. [Medieval Bestiarium, introd. and comm. K. Muratova], Moscow, 1984; О. В. Белова, Славянский бестиарий: Словарь названий и символики [O. V. Belova, The Slavic Bestiarium: Thesaurus of Titles and Symbols], Moscow, 2011, p. 261; Е. В. Пчелов, Бестиарий Московского иарства: Животные в эмблематике Московской Руси кониа XV-XVII веков [E. V. Pchelov, The Bestiarium of the Muscovite Tsardom: Animals in the Emblematics of the Moscow Rus' of the Late Fifteenth - Seventeenth Centuries], Moscow, 2011; Бестиарий в словесности и изобразительном искусстве, сост. А. Л. Львова [Bestiarium in Literature and Fine Arts, ed. A. L. L'vova], Moscow, 2012.

68 Киселева, Интеллектуальный выбор России, р. 274; Симеон Полоцкий, Вертоград многоцветный, подг. текста и комм. А. Хипписли и Л. И. Сазоновой [Simeon of Polotzk, Vertograd Mnogotsvetny, ed. and comm. by A. Hippisli, L. I. Sazonova], Böhlau Verlag - Köln - Weimar - Wien, 1999, vol. 2, p. 347. 
scribe of the patriarch. ${ }^{69}$ Perhaps it was not accidental that the anonymous author mentioned only two names of leaders of Old Believers - not similar in their consistency in faith but having kept allegiance to their ideas: implacable Avvakum and "feigned" Nikita Dobrynin, who made a public repentance at the church porch of the Dormition Cathedral in Moscow, at the Place of Skull, and on the Red Square in November 1667, but later, in 1682, he led an uprising of the guard (streltsy) known as Khovanshchina.

Animalistic metaphors were also used to describe an image of a demon catching souls and the minds of "schismatics":

That thrice cursed devil looks at a man whom he hates, and walks, like a hungry lion, about the flock of Christ, roaring and seeking whom he may devour (1 Pet 5:8), opens his insatiable mouth, as a snake, to devour a man, and belches his killing poison into the ears and hearts of people through cunning and murderous advice from their numerous evil opponents. (f. 463 r)

The representations of the devil as a snake and a lion are similar to those in book miniatures and icons of the Last Judgement and hell. ${ }^{70}$

Other metaphors were connected with domestic animals, especially, with pigs and dogs, their names being used as abusive words. In the polemic discourse of Ivan the Terrible, for instance, the metaphor "political opponent such animal (dog)" was a conceptual one $;^{71}$ it formed a group with an image of dog, which occupied a special place among favourite abusive words of the tsar. $^{72}$ In book culture, the essence of those metaphors did not correspond to interpretations of direct words and their traditional indirect meaning used in

69 Материалы для истории раскола, vol. 1, Moscow, 1875, pp. 140-141, 375-393, 416-425; vol. 2, Moscow, 1876, pp. 5-7, 9-11, 16-17, 25-32, 81-82; Дополнения к Актам историческим, рр. 448-452, 456-458.

70 Д. И. Антонов, М. Р. Майзульс, Демоны и грешники в древнерусской иконографии: Семиотика образа [D. I. Antonov, M. R. Maizuls, Demons and Sinners in Russian Iconography: Semiotics of Imagery], Moscow, 2011.

71 С. Б. Козинец, Словарь словообразовательных метафор русского языка [S. В. Коzіnets, Thesaurus of Morphological Metaphors in Russian Language], Saratov, 2011, pp. 224$225,238$.

72 Д. С. Лихачев, Великое наследие: Классические произведения литературы Древней Pycu [D. S. Likhachev, The Great Heritage: Claccical Works of Literatue of Old Rus'], Moscow, 1975, p. 283 . 
folk culture. ${ }^{73}$ St John Chrysostom explained, for instance, that, in Holy Scripture, those who led a dissipated life were called "pigs," and those who "thoughtlessly raved against God" were called "dogs."

The anonymous author used images of mad pig and dog: such characteristic connected with an aggressive animal behaviour gave a chance to demonstrate cruelty, enmity, persistence, and implacability of the opponent. ${ }^{75}$ Images of mad animals in the text corresponded to various stylistic levels of medieval culture (cf., among others, Mt 8:28-34; Mk 5:1-13; Lk 8:26-33):

But even more they consolidate themselves in evil and are longing for death, like mad pigs to the sea, and they do evil regularly, till God destroys them, oh, the splendour, and grace, and charity, and patience of God. (f. $463 \mathrm{r}$ )

The metaphor of mad dogs was close to the imagery of folk culture. The expression 'mad dog' was used in an abusive meaning in folk speech and served as a nominal expression in the list of metaphorical appellations of that animal: ${ }^{76}$

And who does not see, like mental lunatics, or madmen suffering, and when they break away from the Church, they are grinding teeth at it, like mad dogs because of anger, and because they cannot do it any harm with their bites. (f. 461v)

Among all images of domestic animals, pig and dog were especially in demand regarding Avvakum. Comparing himself with a dog and his children with puppets, Avvakum described their sufferings in exile; an image of an angry dog corresponded to the cruel nature of his tormentors; words "pigs" and "dogs" were used by him as abusive ones. He had never spared rude synonyms of "dog" for his main enemy Patriarch Nikon: "dog of hell" (адов nес), "male greyhound"

73 Е. Е. Юрков, “Метафора лингвокультурного кода “Животные” [Е. E. Yurkov, “Metaphor of the Linvo-Cultural Code 'Animals"'], in: Известия Тульского государственного университета. Гуманитарные науки, 2012, $\mathrm{Nr}$ 1-2, pp. 431-438.

$74 \quad P G 50$, col. 817.

75 А. П. Чудинов, Россия в метаборическом зеркале: Когнитивное исследование политической метафоры (1991-200о) [A. P. Chudinov, Russia in Metaphorical Mirror: Cognitive Study of Political Metaphor (1991-200o)], Ekaterinburg, 2001, гл. 4: Субсфера “Природа" как источник политической метафоры [Chapter 4: Sunsphere 'Nature' as a Source of Political Metaphor]

76 Словарь русского языка XI-XVII в8. [The Dictionary of the Russian Language of the Eleventh-Seventeenth Centuries] Moscow, 2002, iss. 26, p. 11. 
(кобель борзой), "dog Nikon-heretic" (собака Никон-еретик), "That dog, as Nikon, a son of a bitch, lied!" (Вот собака, яко Никон, блядей сын, солгал!), and so on. ${ }^{77}$

Unlike Avvakum, other early Old Believers writers were discreet with zoomorphic metaphors; I failed to find any comparison of their opponents to pigs in the compositions by Nikita Dobrynin, Feodor Ivanov, Epiphanius of Solovki, Avraamy and Lazar. As for zoomorphic images, they preferred to mention dogs, and wild animals - wolves and foxes, to stress cruelty and slyness of their enemies (Patriarch Nikon and his supporters). ${ }^{78}$

The anonymous author was sure that "schismatics" were not able to understand heavenly secrets and the wisdom of Holy Scripture; so, he used one more zoomorphic image, mice:

They bite off holy texts, like mice, and they gain nothing useful for themselves and for their followers, but they start to oppose the heavenly and fearsome and thrilling act, which is above their understanding and their limits, and they quarrel, damned and foul, against God, Who created them, and they check and calculate the day of the Last Judgement and the Second Coming of the Son of God to earth, about the day hidden from us by God. (f. 464r)

The metaphorical image of the mouse in the similar context of the work of book editors was used by Deacon Feodor and then by Archpriest Avvakum. Feodor described the process of editing ancient books: "They wander, sire, like cats among pots, these book editors, and bite off holy texts, like mice. They

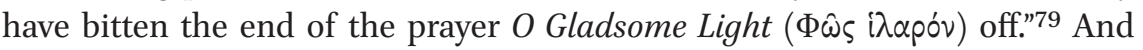
here is a pun by Avvakum: "Such is an invention of these heretics: they catch the tops of the Scripture, as mice bite off the corners of books." 80

To characterize the public behaviour of Old Believers the anonymous author drew the images of madmen and "lunatics." The alleged inconsistency of the "schismatics" was interpreted by the author as an analogue of the changing

77 Житие протопопа Аввакума, pp. 19, 30, 47, 51, 62, 66, 75, 89, 126, 130-131, 145-147, 153, 206, 218, 252, 259-26o, 263, 265-267, 269, 279.

78 Материаль для истории раскола, Moscow, 1678, vol. 4, p. 230; vol. 6, pp. 27, 64, 71, 149, 154, 191, 197, 210, 284, 294, 311, 318, 319; vol. 7, pp. 34-35, 54, 62-63, 68, 71, 78, 82, 89-90, 294-295.

79 Материаль для истории раскола, vol. 6, pp. 32-33.

80 Cit. from: Л. В. Титова, “Дьякон Федор и народная культура” [L. V. Titova, "Deacon Feodor and Folk Culture"], in: Гуманитарнье науки в Сибири, Novosibirsk, 2009, Nr 3, p. 17 . 
moon in the phase of ellipse; the "apostates from Orthodoxy" were called "lunatics" or "mental lunatic-heretics" (мысленными лунатиками-еретиками):

So, opponents of the holy Church turn from goodness to evil, and from one evil to another, because they are not constant in our saving advice, useful for souls, but have doubts and curiosity, as the moon in its full light [...] The author of Proverbs calls such changes mad ones and compares them to phases of the moon (Sir 27:11); when the moon is covered by the earth's shadow, it is overtaken by darkness. Such things happen to people who are not constant in faith. (ff. 46ov, 461r)

Prophets of "strange" doctrines were compared to persons obsessed with demons, who loose conciousness, have disturbed faces, become blind and without memory, are crooked because of physical pain when severe attacks occur. From the point of view of the author, unlike the "bodily obsessed" (беснии же телесно), who lose their contact with reality temporarily, "schismatics" radically lose their unity with the Church and Patristic doctrine and become alienated from spiritual hearing and spiritual sight:

The same thing happens to apostates and schismatics, they forget their mother - the holy Church, in which they were born with water and Holy Spirit, in which they were brought up with the food of the Word of God. They do not remember rules of the holy apostles and regulations of the God-bearing fathers, but they carry about strange doctrines, forgetting an admonition of the teacher of people [...] Alas, awful evil, alas, impious wickers - opponents of the Church, who are grinding teeth, like madmen, destroying their sight and hearing during devilish obsession [...] They destroy their hearing $[\ldots]$ They close their ears and become voluntarily deaf. They lose their sight, when they give up the way of salvation for the sake of the murderous one, and they seek Christ Our Lord where He is absent; God is in the holy Church, as Psalmist says, not with the mobs of the impious, and one should seek Him in His holy Church, nowhere else. (ff. 461-461v, $462 \mathrm{r}$ )

The anonymous author argued that "schismatics" reminded people of both the obsessed and the "lunatics" in their behaviour and their type of speech. Therefore, a "heretic-schismatic" in that homily by Patriarch Nikon appeared as a physically and mentally disturbed person, exactly a "mad lunatic": 
Such opponents rave in their spirit and in their senses; their illness is one of envy and anger, signs are seen on bodies, because such a man, obsessed with self-conceit and stubbornness, not taught, like a madman, turns his head, grinds his teeth, produces foam in a quarrel, shivers, his hair stands up, arms and legs tremble, he breathes hard and groans often, his eyes are awful, his face is pale or blood-red, he has no mind and no memory. Such a self-willed man is an obvious lunatic. (ff. $462 \mathrm{r}-462 \mathrm{v}$ )

Such an analogy between a certain prophet of the Old Believers and a "mad lunatic" would have been made not without reason. Nikon's contemporaries both his supporters and his adversaries - knew well that Bishop Paul of Kolomna in his exile in the Khoutynsky Monastery became a fool for Christ. ${ }^{81}$ However, he is called "fool for the sake of Christ" (безумным Христа ради) only in the Old Believer tradition, whereas the remaining sources said that the bishop became mad because of his sufferings. ${ }^{82}$ The hegumen of the Khoutynsky Monastery gave him the freedom of accessing inside monastery and its surrounds because of the illness, and the bishop used this opportunity to talk to pilgrims and local people with the hope of attracting them to the "ancient true faith": "Brethren! Stand and keep the doctrine of the holy Apostles and holy Fathers [...] Do not be led away by diverse and strange teachings." ${ }^{33}$ The same words of the Apostle Paul were used also by the anonymous author in his didactic appeal to his own flock:

'Do not be led away by diverse and strange teachings' (Hebr 13:9). And more: 'we henceforth be no more children, tossed to and fro, and carried about with every wind of doctrine' (Eph 4:14). Madmen produce foam from their mouths. The same is done by mental lunatic-heretics and schismatics, because, like foul foam, they produce offensive foul before God in the holy Church, its dogmas, its clerics and rites from their lascivious mouths. (f. 461v)

\footnotetext{
81 Материалы для истории раскола, vol. 6, 196-197.

82 Гиббенет, Историческое исследование дела патриарха Никона, р. 1096; Д. А. Урушев, "К биографии епископа Павла Коломенского" [D. A. Urushev, "By the Biography of Bishop Pavel of Kolomna"], in: Старообрядчество в России (хуII-ХХ вв.): Сб. науч. тр., отв. ред. и сост. Е. М. Юхименко, Moscow, 2004, fasc. 3, pp. 29-33.

83 С. А. Белокуров, Сказания о Павле, епископе Коломенском [S. A. Belokurov, Narrations on Pavek, Bishop of Kolomna], Moscow, 1905, iss. 1, pp. 25-26.
} 
The accusatory tone in the description of "schismatics" was designed for that part of audience that had a certain compassion with people upholding their position against liturgical reform:

Some brethren and beloved children, whom I take you for, look upward to see and turn ears to listen to rebellious opponents of the holy Church. They consider and say about themselves: if these people were not Godpleasers, God would not have them such intellect and eloquence. And that is why they want to imitate their evil deeds and bad advice, but it is a temptation. People who are not knowledgeable in writing, ignorant, listen to those of little mind, and they become opponents of the holy Church and discuss it in writing. (f. 464r)

The author, perhaps, interpreted the mood of his compatriots as a manifestation of their instability in faith and that is why - to overcome their doubts - he tried to present the behaviour of the leaders of Old Believers as inappropriate for good Christians by comparing them with animals (rare and domestic both) and ill people.

Convincing the audience to avoid any doctrine not in harmony with Orthodox dogmas, the author at the same time gave a chance to those who opposed liturgical reform, to maximise their positions through repentance and recognition of their delusions before the ecclesiastical court:

And how should those people have been treated? They can be brought to Christ Our Lord through understanding the right holy repentance and communion with the holy sacraments of the pure and life-giving body and blood of the Son of God, with teaching and praying for our salvation. (f. $462 \mathrm{v}$ )

He understood that not all the Old Believers came to repentance; he demanded not only an ecclesiastical but also a criminal court for them - it reflected the decisions of the council of $1667:^{84}$

If they do not convert, it is necessary to fulfil an ecclesiastical execution - the authorities have the right to permit and to prohibit with damnation, and the municipal authorities can heal with punishment. And it is good, because coffins of heresies and dissents keep inside evil and

84 Деяния московских соборов 1666 и 1667 годов [Acts of the Moscow Councils of 1666 and 1667], Moscow, 1893, pp. 81, 82 . 
indomitable things $[. .$.$] If they do not convert and were not obedient,$ they will be destroyed by God here and in the next age. (f. 462v)

The next church council was gathered in 1681; it took a decision to strengthen the repressive measures against "schismatics" who stayed at freedom. At the council, the Church asked tsar Feodor Alexeevich to bring impenitent heretics to the civil court. ${ }^{85} \mathrm{~A}$ severe attitude to "schismatics" was strengthened by the end of the 1680s: tsarine Sophia allowed the application of the death penalty to "schismatics" by burning them alive in the blockhouse, as well as beating them with rods, cruel tortures, exile to monasteries, and forfeiting of property. ${ }^{86}$

Those examples of the unity between the church council and the lay ruler were intended to overcome the spiritual crisis in Russia in the 166o-1680s. They are line with the acts of the Moscow government aimed at the "reclaiming of church customs as the main condition of the prosperity of the land" (на исправление иерковных нравов как главного условия благоденствия страны), together with the inner politics of Patriarch Philarete, the activity of the zealots, and the liturgical reform of Patriarch Nikon, the unfulfilled ecclesiastical reform of the time of tsar Feodor Alexeevich. ${ }^{87}$ The anonymous text, obviously, reflected a hard attitude of the Church and the government to those who disturbed the life of the Church, who supported the opposition, and helped to destroy the prosperity of the country. The author argued that Nikon did not exclude the return of "schismatics" into the Orthodox community for the sake of the unity of the Church, but only on condition that the reform was accepted.

The accusatory style of the actions of the first Old Believers and the strength of their ideas were presented in the newly found text demonstrating that the author stood for the unity of the Church, for the piety of Orthodox doctrine, for establishing inner ecclesiastical order. He knew well the polemical compositions of the first leaders of the "schismatics"; at the same time, he used images and analogies typical for them on both lexical and phraseological levels to build a real diatribe. Such a stylistic principle was aimed at the destruction of ideological opponents by their own methods. The narration of the former comrades of Nikon was often ascribed to the patriarch; many analogies and metaphors were also written under his name - but there were the same

\footnotetext{
85 Акты исторические [The Historical Acts], Saint Petersburg, 1842, vol. 5: 1676-1700, № 75, pp. 111-112.

86 Акты археографической экспедиции [The Acts of the Archaeographical Expedition], Saint Petersburg, 1836, vol. 4: 1645-170o, Nr 284, pp. 419-422.

87 Седов, Закат Московского царства, рр. 422-431, 451.
} 
constructions which had been used by writers of the Old Believers circle. Zoomorphic metaphors and symbols brought the text closer both to the book tradition and to folk culture. The author was well acquainted with Holy Scripture and Patristic, but he was also well acquainted with compositions by adversaries of Patriarch Nikon; the anonymous author tries to unify different stylistic levels - both bookish and folk ones, which made his text more understandable and readable even for people without a high theological education. The author obviously showed that two sides of the conflict - former confederates, then adversaries - used the same methods of polemics, based, according to a definition made by E. K. Romodanovskaya, on the "uniformity of the artistic system," and "common creative rules."

\section{Patriarch Nikon and the Consecration of the Patriarch}

As it was mentioned before, the author of the newly found text drew special attention to those ideas and acts of Patriarch Nikon that had no specific interpretation during his lifetime. One of these situations - his leaving the patriarchal see - occupied a significant place in the composition.

According to the author's interpretation of events, Nikon left Moscow only temporarily and had the intention of returning to his see after solving a conflict with the tsar:

I did not abdicate from my rank as patriarch in a written form, but because of your vain anger towards me said only verbally: I am not a shepherd for you till the time comes. That is why I took my usual patriarchal vestments with me. And so, I went to my monastery because of your cruel and wild rage against me. // And, tsar, if I had not planed on being patriarch, I would not have taken my vestments with me. As the previous metropolitans of Russia, who left their rank and see and went to monasteries forever for the sake of their humility, did not take their hierarchical robes and did not serve. But I served and placed archimandrites, and black priests, and black deacons in my monasteries, and white priests and deacons in their lands, when I was in the Resurrection Monastery, and I placed many people in the priesthood. And to let you know: I am the true Russian patriarch, even I left my episcopal see temporarily because of your tsar's anger, waiting for our reconciliation. (f. $482 \mathrm{v} .-483$ r)

Messages from Patriarch Nikon to the tsar and to Paisius Ligarides, Metropolitan of Gaza, testify that till the moment of leaving the see in 1658 , every three 
years, Nikon asked tsar Alexey Mikhailovich to give him permission to go to a monastery; Lev Lebedev considers that the patriarch saw some mystical sign in the fact that his biography included many three-years periods: he had stayed at Anzer Scete and Kozheozerskaya Hermitage for three years each time; he had served as archimandrite of the Novo-Spassky (New Saviour) Monastery for three years; he had been Metropolitan of Novgorod for three years; after three years of being the patriarch, Nikon asked the tsar to dismiss him for the first time. ${ }^{88}$ The reason for leaving the see was formulated by Nikon in his message to the tsar from the place of his exile in Ferapontovo in 1671: "weakness and lack of mind ... that I had no force for such deed" 89 - the patriarch's doubt of his physical abilities for such great service. In 1662, Nikon evaluated his leaving as a forced one: "our exit was because of zeal, i.e. the necessity. Even if I had such a desire, not at that time, ${ }^{, 90}$ - wrote he to the tsar from exile, perhaps, meaning the previous petitions to dismiss him; in his messages to other people the patriarch said on not just one occasion that his only reason for leaving the see was the tsar's anger. The anonymous author presents this reason as the main one.

Patriarch Nikon had never mentioned in his messages to the tsar how long did he plan to be absent. But in 1662, in his message to Paisius Ligarides he sought understanding and support; that is why the patriarch made analogies between his own act and actions of Christ, apostles and Byzantine hierarchs who had to hide themselves from persecutors:

Our departure was not because of our negligence of the flock, but for heavenly reasons, as it was written in the New Testament, how Christ ran away not just once from calumny of Herod and the Jews secretly, and so did the apostles, and Paul from Damascus, and Peter ran from the jail, and others; the same was done by hierarchs, as well as Gregory the Theologian [sc., of Nazianzus], and Athanasius the Great, who escaped from his tormentors. ${ }^{91}$

Nikon, as well as the participants of the Council of 1660, referred to the ecclesiastical rules, which admit as legal the actions of hierarchs who temporarily left their flock:

88 Л.

89 Севастьянова, Эпистолярное наследие патриарха Никона, р. 462.

90 Ibid., p. 410.

$91 \quad$ Ibid., p. 597. 
They also did not write the 19th canon of the Council of Sardis, that bishops leaving their see because of persecutions and staying in other cities till the anger subsides are not guilty. ${ }^{92}$

It is clear that in his message to Ligarides Nikon did not write of his denial of the rank of patriarch but of leaving the see; and that deed, on the opinion of Nikon, was done according to the precedents mentioned in the Gospel and known in the Byzantine history. Nikon did not remind such cases from the Russian history - perhaps, because the addressee was Greek cleric; but in Old Russia there were precedents of a bishop leaving to go to a monastery for the sake of giving a lesson to some ruler. So, after a ceremony in the Assumption Cathedral in the Moscow Kremlin, Prince Ivan III reprimanded Metropolitan Gerontius (1473-1489) for an incorrect liturgical procession; the metropolitan left his see, and the prince had to "ask him humbly" to return. ${ }^{93}$ After the death of Nikon one of his followers strengthening the positions of the Church, Patriarch Joachim, repeated the act of Nikon: in 1682, he adepted the monastic habit because of his being disgraced by tsar Feodor Alexeevich. ${ }^{94}$

As is well known, leaving the see by Nikon was explained by his understanding of patriarchy as one of charisma received through consecration. ${ }^{95}$ Interpreting the patriarchal consecration not as an act of coming to a certain see but as a special consecration, Nikon connected his own title of patriarch with the special rank; therefore, in this case his act could not be a manifestation of his refusal to remain a bishop. ${ }^{96}$ Not accidentally Nikon mentioned in his

$92 \quad$ Ibid.

93 Макарий (Веретенников), “Святейший Патриарх Никон” [Makarios (Veretennikov), "The Most Holy Patriarch Nikon"], in: Альфа и Омега (2006), Nr 3 (47), pp. 77-75. The author of the article gives examples of "leaving the see" by Russian metropolitans and enforcement to do it by lay powers in the sixteenth and seventeenth centuries: under Basil III - Metropolitan Varlaam (1511-1522), under Ivan the Terrible - Metropolitans Daniel (1522-1539), Joasaph (1539-1542), Athanasius (1564-1566), Philip (1566-1568), Cyril (1568-1572), Antonius (1672-1581), under Boris Godunov - Metropolitan Dionisius (15811589), under False Dmitry I - the first Russian Patriarch Job (1589-1605), under Basil Shuisky - Patriarch Ignatius the Greek (1605-1606), at the period of Seven Boyars rule and Polish troops in the Moscow Kremlin Patriarch Hermogen (1606-1611) was imprisoned in the Chudov Monastery (the monastery of the Wonder of St Michael Archangel) and died there.

94 Седов, Закат Московского иарства, р. 447.

95 Успенский, Царь и патриарх, рр. 103-107.

96 С. К. Севастьянова, “Повторная хиротония в трактовке патриарха Никона” [S. K. Sevastyanova, "Repeated Cheirotonia in the Interpretation of Patriarch Nikon"], in: Сибирский филологический журнал (2013), Nr 4, pp. 30-36; еadem, “Хотел ли патриарх 
message to the tsar that, leaving Moscow, he took his episcopal clothes to the Resurrection Monastery; he used them for church services and for the ordination of priests and deacons to the monasteries founded by him earlier. This is a fragment from a Nikon's message to the tsar written in 1659:

One dalmatic was taken, and it is not expensive, a simple one; an omophorion was sent to me by Gabriel, metropolitan of Chalcedon. And not for gain, but till I am alive I need to send prayers for the spiritual salvation of you, the tsar, and for bodily health, and after my death let it be laid on my body. ${ }^{97}$

And the following text is on the same topic - in an intercepted epistle to Dionysius, patriarch of Constantinople in 1666:

And that is why I took the most humble and bad episcopal dress, and went from the holy church to the city church of the Resurrection Monastery built by you, and I did not take any property, except one dalmatic, and one mitre, and one piece from other bishop's clothes, non-expensive, for the service, not to leave the office of bishop, and I went away, and many lie, saying that I voluntarily refused to be bishop. ${ }^{98}$

A special understandings of Nikon's patriarchal consecration was not in accordance with examples known in the history of the Russian Church, when hierarchs left their sees refusing ranks and titles, after which they were called "former." 99 The fact is that hierarchs, having left the see were no longer called hierarchs and did not serve as bishops: they signed a typical document of resignation and adopted the ordinary monastic life. They had no more right for "acting a hierarch" and to be called archbishops. ${ }^{100}$ There was a case of the metropolitan Zosimus, who denied that his dismissal by the great prince was canonically legal and, therefore, he still considered himself as a hierarch: in

Никон отлучить царя Алексея Михайловича от христианства? 1-е Возражение Никона на «вопросоответы» боярина Стрешнева и Паисия Лигарида и его литературные источники" ["Whether Patriarch Nikon Wanted to Excommunicate Tsar Alexey Mikhailovich? The First Objection of Nikon to the Erotapokriseis by Boyarin Streshnev and Paisius Ligarides and Its Literary Sources"], in: Palaeoslavica, 21/2 (2013), pp. $291-303$.

97 Севастьянова, Эпистолярное наследие патриарха Никона, р. 391.

98 Ibid., p. 618.

99 Успенский, Царь и патриарх, р. 105.

$100 \quad$ Ibid., pp. 57, 67. 
1496, he had communion in the Holy Trinity St. Sergius Monastery "on the round [bishop's] hassock in complete episcopal apparel."101 At the council of 1660, they discussed a specific issue: whether to treat Nikon as a hierarch or not. In 1662, having received the decision of the council and its circumstances, Nikon wrote to Ligarides:

And the tsar gathered all hierarchs [...] and ordered them to write, as we voluntarily leave the see under oath $[. .$.$] and to write on me with their$ own hands, let me not be patriarch. ${ }^{102}$

Different understanding of the rank of patriarch by Nikon and his contemporaries could be a reason for the special attention of participants of the council of 1660 to exact formulas of the act of Nikon and the essence of his speech: it was important to sort out the issues put at the council - he resigned from his see, but whether he left the see voluntarily or by force, whether he was to return or not and under what terms. The unknown author put a certain and clear definition of that act into the mouth of Nikon: "I am not a shepherd for you till the later on, said Nikon in his parting with his people; I am a true Russian patriarch, in spite of the fact I have left temporarily my episcopal see." He called himself a Russian patriarch; therefore, he did not connect his service with any concrete location. Nikon's contemporaries, eyewitnesses of the events in the Assumption Cathedral on July 10, 1658, gave a confused account, retelling Nikon's speech to his people, which is why the ecclesiastical judges could not deliver an unambiguous decision. There are several quite different interpretations of the events of July 1658 and the speech by Nikon by eyewitnesses. In 1660, Prince Alexey Nikitich Trubetskoy and the Duma official (d'yak) Larion Lopukhin recounted their talk with Nikon in the Resurrection Monastery on July 12, 1658:

Patriarch Nikon said: I shall not change my word, and I have made a promise not to be patriarch for a long period [...] And I do not want to be patriarch any more: and if I ever want to be patriarch, let me be damned and under anathema. ${ }^{103}$

\footnotetext{
101 Успенский, Избранные труды, рр. 91-92, 116.

102 Севастьянова, Эпистолярное наследие патриарха Никона, р. 597.

103 Дело о патриархе Никоне [The Criminal Case of Patriarch Nikon], Saint Petersburg, 1897, pp. $16-17$.
} 
In March 166o, stol'nik Matvey Pushkin recollected his talk with Nikon which happened in July 1658 :

He left the see but he did not leave the episcopal duties [...] And the patriarch had decided long ago that he would not stay patriarch in Moscow $[. .$.$] And if the great prince allows him, the patriarch will get to Mos-$ cow, and, on the order of the great prince, the patriarch will bless the newly selected one and, taking a merciful forgiveness of the great prince he will concelebrate with the (other) hierarchs and bless them, after which he will go to a monastery. ${ }^{104}$

In the first case patriarchy was interpreted as a service limited to a certain see. In the second case, thanks to an adjustment "in Moscow" and an agreement of Nikon on the elections of a new patriarch, the concept of patriarchy meant a special act of consecration. Laymen are hardly knowledgeable enough in the sphere of ecclesiastical law, in for their duties defining the rank of patriarch, which is why we can understand the inconsistency in the description of Nikon's action. There was no unanimity among clerics in the interpretation of the Nikon's farewell speech of Nikon: metropolitans and archpriests, priests and church singers testified that Nikon called himself either patriarch or pastor and sometimes he withdrew from the see of Moscow and even from the priesthood itself:

'From that time on, I shall not be your patriarch! [...] And he resigned his episcopal rank, and he said: I was no more your pastor" (Pitirim, metropolitan Krutitsky); 'I shall not be your pastor and shall not be called patriarch of Moscow, and he laid down his rank to subdeacons and his deacons" (Joseph, hegumen of the Znamensky Monastery); 'and that is why, from this time on, I can bear such a burden no more? And I shall not be called patriarch of Moscow" (Ivan Shchepotkin); 'then I shall not be patriarch from this day" (singer d'yak Denisko Fedorov) and others. ${ }^{105}$

We can note that Nikon's interpretation of patriarchy reminded somehow the concept of pope in Roman Catholic Church. ${ }^{106}$ At the time of tsar Alexey Mikhailovich thanks to these ideas and to Nikon's position they began to create an image of patriarch Nikon as "papist"; and the first person who promoted

\footnotetext{
104 Ibid., pp. 19-20.

105 Ibid., pp. 21-52.

106 Detailed: Успенский, Царь и патриарх, p. 106.
} 
that concept was Paisius Ligarides, metropolitan of Gaza. ${ }^{107}$ The son of Alexey Mikhailovich, tsar Feodor Alexeevich, however, agreed with Nikon on the point of the special position of the patriarch in the system of the Church. Not long before Nikon's death in 1681, he invented a plan of a large-scale ecclesiastical reform: pope, 4 patriarchs, 12 metropolitans, and 70 bishops; according to some sources, he supposed Nikon would occupy the place of the pope. That reform and establishing the rank of the pope were to change radically a situation in the Moscow Church and in the Orthodox world in general, having influence in the traditional Pentarchy; the aim was to demand the chief role in ecumenical Orthodoxy for the patriarch of Moscow. ${ }^{108}$ Tsar Alexey Mikhailovich wanted to implement an idea of the universal Orthodox monarchy with the support of Nikon, and tsar Feodor Alexeevich tried to do the same - that is why he brought Nikon back from his exile and demonstrated the tsar's good will to him.

\section{Tsar Alexey Mikhailovich and Patriarch Nikon}

The anonymous author considers that a reason for the Church Dissent was not the book reform of Patriarch Nikon, but the absolutist policy of tsar Alexey Mikhailovich:

You, tsar, broke the spiritual unity and shook the holy Church - the bride of Christ. And because of that crime of yours, which was directed baldly against the holy Church which you wanted to possess in the manner of a layman, sending away the hierarchs, as her groom, and that is why dissent and discords began in the holy apostolic Church because of your persecutions, tsar, and robbery and prevailing over her, and not because of corrections of ancient books and rites by me, only because of your evil badness, most harmful for the Church, and because of you are the most evil desire. Therefore, evil-minded and non-obedient rebels and schismatics appeared in the holy Church. You, tsar, came into the most holy

107 Г. Воробьев, “Паисий Лигарид (1662-1666)" [G. Vorobiev, "Paisius Ligarides (16621666)”], in: Русский архив, Moscow, 1893, book 1, pp. 5-32; П. Пирлинг, “Паисий Лигарид. Дополнительные сведения из римских архивов" [P. Pierling, "Paisius Ligarides. Additional Data from Archives of Rome"], in: Русская старина, vol. 109, iss. 1, Saint Petersburg, 1902, pp. 337-351; А. С. Елеонская, Русская публицистика второй половины XVII века [A. S. Eleonskaya, Russian Political Essays of the Secon Half of the Seventeenth Century], Moscow, 1978, p. 56 . 
church yard not through the doors, but wrongly over the fence, like a robber and thief. (f. 482v)

Patriarch Nikon wrote about the consequences of absolutist aspirations of the tsar, openly criticizing the Synodal Code (Sobornoe Ulozhenie) and the organization of the Monastery Prikaz (Department), and arguing against the appropriation of monastery lands and ecclesiastical property by state officials, as well as against a call for priests to enter the state service, including the military:109

I, Nikon, did not revile the tsar, and do not revile him, but I speak about his evil, and I shall not stop doing it! - wrote Nikon in his 26 objections; 110 'Besides, with violence, everywhere in holy metropolises, and bishoprics, and in holy monasteries you violently take estates and other property without any council and blessing without any mercy. And you turned into nothing all the rules of the holy fathers and righteous tsars and grand princes, Greek and Russian! [...] Lay judges judge and enforce hierarchs, and archimandrites, and hegumens, and priests, and all clerics [...] you took many estates, settlements, and villages, and lakes, and saltworks, and forests given for eternal heritage to God's churches and holy monasteries and you reject God!' - Nikon was disturbed as he described it in his letter to tsar Alexey Mikhailovich after December 17, 1661; he asked the tsar: 'Let Our Lord give you His grace and mind to be merciful, and humble, and quiet, and to look at all God's commandments and to keep them in practice, and do not offend us, your humble devotees, and not to take us to the lay court against the law, and do not insult us in anything, and do not violate the holy churches and monasteries.'111

The state of the persecuted Church was characterized by Nikon as something apocalyptic; he interpreted famous images, symbols, and episodes from the Book of Revelation by the Apostle John in the context of a certain historical situation. ${ }^{112}$ As for the idea of the correction of books as a reason for the dissent, an accusation of Nikon in that reform was typical for Old Believers of the

\footnotetext{
109 Севастьянова, Эпистолярное наследие патриарха Никона, pp. 182-186.

110 Patriarch Nikon on Church and State: Nikon's «Refutation», ed. with introduction and notes by V. A. Tumins and G. Vernadsky, Berlin - New York - Amsterdam, 1982, p. 351.

111 Севастьянова, Эпистолярное наследие патриарха Никона, pр. 401-402, 404.

112 Ibid., pp. 399, 702-703.
} 
166os-1670s. Meanwhile, according to Gregory Neronov, Nikon sometimes allowed the use of both old and new books in liturgical practice. ${ }^{113}$

Defending the position of Patriarch Nikon in his accusation of tsar Alexey Mikhailovich concerning the woes of the Russian Church, the anonymous author went even further: in his opinion, the absolutist policy had sadder results in weakening the rights of the Church, losses of lands and other property, because there were also such consequences, as destroying its "spiritual unity," her inner agreement of mind. Patriarch Nikon had never formulated the tsar's "crime" in such a way. Turning to the experience of the Church of Constantinople, the anonymous author appealed to the printed Kormchaya (Moscow, 1653), and literally copied the first part of the council's proceedings (Volumes of Unification), published by Nicholas Mystikos, patriarch of Constantinople, in 920. The author inscribed to Patriarch Nikon a fragment of those proceedings explaining the unification of Churches of Apostolic times through principles of common faith, the verity of the tradition, the power of preaching, the high spirit of believers, the purity of clerics, and the open life of hierarchs, the outstanding love of the Church, and boundless obedience to it. On the eve of the reforms of Peter the Great, Nikon's accusation addressing higher state authorities in their attempts to weaken the spiritual power of the Church sounded like a prophecy.

One more accusation of tsar Alexey Mikhailovich, unknown in the works by Patriarch Nikon, was in his superfluous credulity of his milieu and in his uncertainty in taking decisions. Describing the conflict between the tsar and the patriarch, Nikon himself often mentioned some slanders of his enemies. ${ }^{114}$ In the newly found text, the topic of slander of the patriarch in the closest circle of the tsar receives rather radical development: in that version all accusations were direct and rude, the Tsar looked feeble and craven because he allowed his subjects to prevail over him in state affairs and in the issues of the destiny of the Russian Church:

You, tsar, by yourself, together with your evil indulgent counsellors, composed a cruel and cunning plan of enforcement over me, and you forced me to give you my hierarchical rank, and you laid your hands on it, and

113 “Записка о жизни Ивана Неронова" ["A Note on the Life of Ivan Neronov"], in: Памятники литературы древней Руси, Moscow, 1989, ХVII век, кн. вторая, p. 341; Т. А. Опарина, “Поиски церковного идеала Ивана Неронова” [T. A. Oparina, "Searches for the Ecclesiastical Ideal by Ivan Neronov"], in: Человек верующий в культуре Древней Руси, отв. ред. Т. В. Чумакова, Saint Petersburg, 2005, pp. 72-82. 
me, your humble father, offended completely with your unjustly and sly judgement, and you impoverished and robbed holy churches and monasteries, and you took their lands by force without truth [...] And you gave a chance to your smarmy freeloaders to tell you their speeches, and to prevail over you, and you gave us no humble //mercy or grace, as it happened before, except your rage and anger, not just towards me, sinful Patriarch Nikon, but also towards God Himself. (f. 483r-483v)

On the base of personal authority of Patriarch Nikon, the author called all people interested in the destiny of the Russian Orthodox Church, as well as those who shared Nikon's ideas of a strong theocratic state and ecumenical Orthodoxy, which trusted in high moral image of the Orthodox priest supporting ecclesiastical discipline and social service of the Church, and its spiritual unity. If we use the words of the Russian historian A. V. Kartashev on the last preSynodalical Patriarch Hadrian, the anonymous author expressed "the 'quiet considerations' of all Russian hierarchy after its abjuration of Nikon'sheritage." 115

The personality of Patriarch Nikon is presented in the newly found text as a versatile one: a bright preacher, defender of the Church, keeper of the traditions of Russian monasticism praying for the people of Russia, a victim of the tsar's despotism, and a deep ascetic. The text can be put into the context of evaluation of the personality and activity of Nikon; in the second half of the seventeenth century, his splendid figure was rather natural in the historical and literary background of the epoch: apologetic writers worked with the written heritage of the patriarch and added new data about his biography which existed earlier in the oral tradition only; ${ }^{116}$ in the 1680s-169os, leaders of the Resurrection Monastery finished the construction of the ensemble of the cloister adorned with verses on stone panels glorifying Nikon in his personality and deeds; ${ }^{117}$ next patriarchs, Joachim and Hadrian, in spite of their contradictory

115 А. В. Карташев, Очерки по истории Русской Церкви [A. V. Kartashev, Essays on the History of the Russian Church] Moscow, 1997, vol. 2, p. 171.

116 О. Ю. Майорова, “'Известие о рождении, о воспитании и о житии Никона, патриарха Московского и всея Руси'. (Вопросы истории текста)” [О. Yu. Majorova, “A Report on the Deliverance, Bringing Up and Life of Nikon, Patriarch of Moscow and All Russia (Problems of the History of the Text)"], in: Источники по истории народной культуры, Syktyvkar, 1991, pp. 25-31.

117 Леонид (Кавелин), архим., Историческое описание ставропигиального Воскресенского, Новый Иерусалим именуемого, монастыря [Archim. Leonid (Kavelin), Historical Description of the Stauropigial Resurrection Monastery, Named New Jerusalem], Moscow, 1876, pp. 92-98 (stone monastery 'chronicle'); А. М. Панченко, Русская стихотворная культура ХVII века [A. M. Panchenko, Russian Poetic Culture of the Seventeenth Century], 
approach to the predecessor, followed his ideas of the spiritual role of the Church in the life of society. ${ }^{118}$

Who could be the author of that text? Evidently, someone from the closest circle of Patriarch Nikon - one of his disciples or admirers of his ideas and deeds. Without any doubt, he was a talented person. The text contains verses with skilled metres and with occasional rhymes. The author carefully selected metaphorical images of the Church and transformed symbols of Nikon's architectural decoration (boat, earthen sky, grapes) ${ }^{119}$ into literary formulas, explaining the theological conception of the patriarch performed in churches of the New Jerusalem by Moscow and other monasteries founded by Nikon.

A selection of sources used by the author recommends him as a well-educated man. First of all, it includes Orthodox canonical books, collections of ecclesiastical and secular legal texts on the topic of Church regulation and ecclesiastical court: among them, the Book of Faith, Kormchaya, Stoglav ("The Hundred Chapters," 1551). The author used commentaries by Holy Fathers on liturgy, for instance, an Old Russian compilation known as The Commented Service, and such a publication as Skrizhal'. The author paid special respect to the works of Joseph of Volokolamsk, so he copied some passages on the collective prayer from his book The Enlightener. Prayers to the Virgin Mary, cited in the text under the name of Patriarch Nikon, were taken from the Akathistos and festival services, and personal prayers of Nikon were composed from

Leningrad, 1976, pp. 111-112; Зеленская, Святьни Нового Иерусалима, pp. 312-325; А. Г. Авдеев, Старорусская эпиграфика и книжность: Ново-Иерусалимская школа эпиграфической поэзии [A. G. Avdeev, Old Russian Epigraphics and Book Culture: New Jerusalem School of Epigraphic Poetry], Moscow, 2006.

118 Д. Ф. Полознев, “Московские патриархи Иоасаф II, Питирим, Иоаким и Адриан” [D. F. Poloznev, "Moscow Patriarchs Joasaph II, Pitirim, Joachim, and Adrian"], in: Макарий (Булгаков), митр., Московский и Коломенский, История Русской Церкви [Metr. Macarius (Bulgakov), History of Russian Church], Moscow, 1996, book 7, pp. 470495; Г. А. Скворцов, Патриарх Адриан: Его жизнь и труды в связи с состоянием Русской Церкви в последнее десятилетие хvіг века [G. A. Skvortsov, Patriarch Adrian: His Life and Works in the Context of the State of the Russian Church in 169o-s], Kazan, 1913; А. П. Богданов, “Святительский суд патриарха Адриана” [А. P. Bogdanov, “The Patriarchal Court of Patriarch Adrian"], in: Религии мира: История и современность, Moscow, 2004, pp. 123-137; Г. М. Зеленская, "Патриарх Иоаким и монастыри патриарха Никона" [G. M. Zelenskaya, "Patriarch Joachim and the Monasteries of Patriarch Nikon"], in: Макариевские чтения. Иерархия в Древней Руси. Материалы хІІ российской научн. конф., посвященной памяти святителя Макария, Moscow, 2005, iss. 12, pp. 8o-87.

119 Г. М. Зеленская, Патриарх Никон - зодчий Святой Руси [G. M. Zelenskaya, Patriarch Nikon as the Architect of the Holy Rus'], Moscow, 2011, pp. 69-261. 
fragments of a popular treatise of the fifteenth century, The Imitation of Christ by the German Catholic monk Thomas von Kempen (Dehl Monastery, 1647). ${ }^{120}$ Numerous samples from Judaic history were taken from the Bible, and those from Russian history testify to the interest of the author in local chronicles which were used by him with didactic aims - for the sake of the idea of a certain correct implementation of such historical experience. The author accuses his opponents by using some zoomorphic images - mainly, from the composition On Some Features of the Nature of Animals by Damascene the Studite. All those sources are characteristic of the versatile and updated literary context of Russian culture of the seventeenth century; against such a background, the author created a many-faceted image of Patriarch Nikon and presented his key ideas.

The anonymous text can be dated using the following means. In the fragment on some unusual natural phenomena in Russia there is a date 6700 (1191/92); it is said: "From that time on almost 500 years passed" (f. 473v); we may suppose that the author speaks about approximately 1691/92. Besides, he made a noteworthy description of a manifestation of three suns with a horned moon in the sky made by artists. There were European drawings of the natural phenomenon of March 4, 1691 - it was also mentioned in the Cronicle of Chernigov. ${ }^{121}$ These dates -1691 and 1692 - do not contradict dating the paper on the base of its watermarks (see footnote 1). So, we may conclude that the text was composed in the very beginning of the $1690 s$.

120 М. Г. Логутова, “Авторство книги «О подражании Христу» и рукописи Российской национальной библиотеки” [M. G. Logutova, "The Author of the Book Imitatio Christi and Manuscripts of the State Russian Library"], in: Западноевропейская культура в рукописях и книгах Российской наииональной библиотеки: Памяти Александры Дмитриевны и Владимира Сергеевича Люблинских, Saint Petersburg, 2001, pp. 240246. The treatise by Thomas von Kempen in the translation by Nasturel was known to Nikon: in 1658 , he gifted its publication of 1647 to the library of the Resurrection Monastery (New Jerusalem); this copy with a sign about the provenance is kept now in the Russian State Archive of Old Acts (Moscow); cf. А. Н. Стрижев, “Фома Кемпийский в России" [А. N. Strizhev, "Thomas von Kempen in Russia”], Богословские труды, 40 (2005), pp. 368-369.

121 Д. О. Святский, Астрономия Древней Руси [D. O. Svyatsky, Astronomy in Old Russia], предисл., комм., дополн. М. Л. Городецкого, Moscow, 2007, pp. 79-8o. I would like to express my gratitude to S. M. Shamin for advice and the reference to this book. 